\section{Dr. Daniela}

Brečko, Planet GV

KARIERNA SIDRA IN NAČRTOVANJE IZOBRAŽEVANJA (II. DEL) Karierna sidra kot relativno trajna struktura osebnosti in vpliv na načrtovanje izobraževanja

\title{
POVZETEK
}

$V$ drugem delu prispevka, ki se navezuje na prispevek iz prve številke letnika 2006 revije Andragoška spoznanja, bomo predstavili raziskavo o kariernih sidrih iz leta 2004, ki jo bomo primerjali z raziskavo iz leta 2000 , in skušali odgovoriti na vprašanje, ali se karierna sidra pri posameznikih spreminjajo ali ne, ali predstavljajo relativno trajno notranjo strukturo posameznika ali ne in kdaj se, če so relativno trajna, dokončno izoblikujejo. Ali lahko spremembe kariernih sider povežemo z različnimi poklici?

$V$ prispevku bomo skušali izluščiti podobnosti in razlike pri načrtovanju izobraževanja pri posameznikih z istimi oz. različnimi kariernimi sidri in ugotavljali vserazsežnost vplivanja kariernih sider na načrtovanje formalnega in neformalnega izobraževanja, motive za izobraževanje in celo na pripravljenost za prostovoljno delo.

Ključne besede: kariera, karierno sidro, izobraževanje, poklic, poklicna pot, učna pot

prvem delu prispevka, torej iz podatkov, pridobljenih v letu 2000, smo lahko dokončno preverili in potrdili dejstvo, da $\mathrm{v}$ slovenskem prostoru obstaja osem kariernih sider, ki močno vplivajo na izbor poklica. Nismo pa še zbrali dovolj podatkov, da bi lahko preverili in odgovorili na vprašanje, ali se karierna sidra spreminjajo ali ne. Že pred pričetkom raziskave smo se namreč spogledovali z mislijo, da se karierna sidra, ko so enkrat oblikovana, ne spreminjajo več. Pri postavitvi te hipoteze smo izhajali iz Sheinovih ugotovitev (Shein, 1986) in raziskav, ki jih je izvajal v ameriškem prostoru.

\section{SE KARIERNA SIDRA SPREMINJAJO?}

Kot smo že omenili v prvem delu prispevka, smo se odločili za longitudinalno raziskavo, pri čemer smo želeli raziskati, ali se karierna sidra spreminjajo ali ostajajo razmeroma trajna notranja struktura posameznika, ki ga vodi po karierni poti. S tem namenom smo za sodelovanje $\mathrm{v}$ raziskavi prosili iste udeležence kot leta 2000. Na ponovno raziskavo, ki smo jo izvedli sredi leta 2004, se je odzvalo 197 posameznikov (torej 74,2 odstotka vzorca iz leta 2000). To smo šteli za precejšen odziv, 
Tabela 1: Zastopanost poklicev $\vee$ raziskavi Karierna sidra $v$ letih 2002 in 2004

\begin{tabular}{|c|c|c|c|c|}
\hline \multicolumn{2}{|c|}{$\begin{array}{l}\text { Zastopanost poklicev } \\
\text { v raziskavi leta } \\
2002 \text { in } 2004\end{array}$} & $\begin{array}{l}\text { Stevilo } \\
\text { leta } 2004\end{array}$ & $\begin{array}{l}\text { Odstotek } \\
\text { glede na } \\
\text { vzorec iz } \\
\text { leta } 2000\end{array}$ & $\begin{array}{l}\text { Veljavni } \\
\text { odstotek } \\
\text { v letu } \\
2004\end{array}$ \\
\hline \multirow{15}{*}{$\begin{array}{l}\text { Delovno } \\
\text { mesto } \\
\text { leta } 2004\end{array}$} & direktor podjetja & 31 & 11,9 & 15,7 \\
\hline & vodja oddelka/enote & 20 & 7,7 & 10,1 \\
\hline & tajnica/poslovna sekretarka & 34 & 13,1 & 17,2 \\
\hline & organizator dela/organizacija dela & 8 & 3,1 & 4,0 \\
\hline & pravna služba & 11 & 4,2 & 5,6 \\
\hline & komercialist & 4 & 1,5 & 2,0 \\
\hline & inženir & 12 & 4,6 & 6,1 \\
\hline & ekonomist/finančni analitik & 12 & 4,6 & $\overline{6,1}$ \\
\hline & kadrovski delavec & 11 & 4,2 & 5,6 \\
\hline & zdravnik & 6 & 2,3 & 3,0 \\
\hline & učitelj/profesor & 11 & 4,2 & 5,6 \\
\hline & upravni delavec & 26 & 10,0 & 13,1 \\
\hline & drugo & 12 & 4,6 & 6,1 \\
\hline & Skupaj & 198 & 76,2 & 100,0 \\
\hline & Število nesodelujočih $v$ drugi raziskavi & 62 & 23,8 & \\
\hline \multicolumn{2}{|c|}{ Skupaj vzorec 2002 in 2004} & 260 & 100,0 & \\
\hline
\end{tabular}

če upoštevamo, da so vmes minila štiri leta in nekateri niso bili več dosegljivi na starem naslovu. $V$ drugem delu raziskave smo jih $\mathrm{s}$ pisno prošnjo povabili $\mathrm{k}$ sodelovanju oziroma $\mathrm{k}$ izpolnitvi vprašalnika, ki je bil tokrat informacijsko podprt in so ga torej vsi respondenti izpolnili prek interneta. Vprašalnik je vseboval tri dele: vprašalnik o kariernih sidrih, vprašalnik o načrtovanju izobraževanja in vprašalnik o osebnih podatkih, namenjenih statistični obdelavi vzorca. Po obdelavi osnovnih statističnih podatkov smo s ponovno analizo kariernega sidra pri udeležencih raziskave želeli ugotoviti, ali se je karierno sidro, ki smo ga ugotovili leta 2000, v obdobju štirih let spremenilo ali ne. Najprej pa si oglejmo, kateri poklici so bili zastopani tudi $v$ raziskavi iz. leta 2004 glede na raziskavo leta 2000 .
Podatke o poklicih smo zbrali in primerjali v tabeli 1, tako da smo najprej vključili vse anketirance, tako tiste, ki so sodelovali v obeh raziskavah, kot tudi tiste, ki so sodelovali lc $\mathrm{v}$ raziskavi v letu 2000 . $V$ tabeli 2 pa smo upoštevali le tiste anketirance, ki so sodelovali $\mathrm{v}$ obeh raziskavah, in izločili tiste, ki v ponovno raziskavo leta 2004 niso bili vključeni $\mathrm{z}$ namenom, da bi ugotovili, ali so se karierna sidra pri posameznikih po preteku štirih let spremenila ali ne, in če so se, koliko sprememb je bilo. Anketirance smo razporedili vzdolž prevladujočih kariernih sider, ki so jim pripadali v letu 2000.

Iz tabele je moč razbrati, da smo pri skupno 197 posameznikih ugotovili 21 sprememb kariernih sider oziroma na 10,7 odstotka populacije vzorca iz leta 2004 , pri 89,3 odstotka 
posameznikov pa spremembe prevladujočega kariernega sidra nismo ugotovili. Vrednost hi-kvadrata oziroma Kulbackovega 21. pre-

Karierna sidra predstavljajo relativno trajno notranjo strukturo posameznika. izkusa $\left(k^{2}=16,712, \mathrm{~g}=7\right.$, $\dot{\alpha}=0,019$ ) pokažc, da je vrednost statistično pomembna in $s$ tveganjem, manjšim od 0,1 odstotka, lahko trdimo, da je karierno sidro razmeroma trajen sklop vrednot in motivov, ki se z leti ne spreminja. Ugotavljanje stopnje povezanosti na podlagi kontingenčnega koeficienta $(\mathrm{C}=$ 0,236 ) pokaže, da je povezanost med spremenljivkami $v$ vzorcu srednje velika in stati- stično pomembna $(\dot{a}=0,113)$.

$\mathrm{S}$ tem smo dokončno potrdili hipotezo oz. tiditev, da se karierna sidra, ko so enkrat izoblikovana, ne spreminjajo več in predstavljajo relativno trajno notranjo strukturo posameznika. Trdimo torej lahko, da ostajajo razmeroma trajen skupck vrednot, ki usmerjajo posameznika na njegovi karierni poti.

Glede na metodologijo, ki smo jo uporabili v obeh raziskavah, smo lahko po raziskavi leta 2004 primerjali in raziskali tudi spremembc kariernih sider glede na poklic oziroma delovno mesto posameznika, da bi ugotovili, ali je na določenih delovnih mestih prišlo do sprememb kariernih sider in kakšne so bile.

Tabela 2; Število sprememb kariernih sider od leta 2000 do leta 2004

\begin{tabular}{|c|c|c|c|c|c|}
\hline & & & \multicolumn{2}{|c|}{ Sprememba kariernega sidra } & \multirow{2}{*}{ Skupaj } \\
\hline & & & $\mathrm{NE}$ & DA & \\
\hline \multirow{16}{*}{ Sidro 2004} & \multirow{2}{*}{ TFS } & število & 40 & & 40 \\
\hline & & $\mathrm{v}$ odstotkih & 100,0 & & 100,0 \\
\hline & \multirow{2}{*}{$\mathrm{MS}$} & število & 34 & 7 & 41 \\
\hline & & v odstotkih & 82,9 & 17,1 & 100,0 \\
\hline & \multirow{2}{*}{ SSN } & število & 17 & 2 & 19 \\
\hline & & v odstotkih & 89,5 & 10,5 & 100,0 \\
\hline & \multirow{2}{*}{ SVS } & število & 22 & 2 & 24 \\
\hline & & v odstotkih & 91,7 & 8,3 & 100,0 \\
\hline & \multirow{2}{*}{ SPU } & Število & 5 & & 5 \\
\hline & & v odstotkih & 100,0 & & 100,0 \\
\hline & \multirow{2}{*}{$\mathrm{SP}$} & število & 34 & 8 & 42 \\
\hline & & v odstotkih & 81,0 & 19,0 & 100,0 \\
\hline & \multirow{2}{*}{ SI } & število & 14 & 2 & 16 \\
\hline & & v odstotkih & 87,5 & 12,5 & 100,0 \\
\hline & \multirow{2}{*}{ SŽS } & število & 10 & & 10 \\
\hline & & v odstotkih & 100,0 & & 100,0 \\
\hline \multirow{2}{*}{\multicolumn{2}{|c|}{ Skupaj }} & število & 176 & 21 & 197 \\
\hline & & v odstotkih & 89,3 & 10,7 & 100,0 \\
\hline
\end{tabular}

Okrajšave:

TFS - tehnično-funkcionalno sidro, MS - menedžersko sidro, SSN - sidro samostojnosti in neodvisnosti, SVS - sidro varnosti in stabilnosti, SPU - sidro podjentiske ustvarjalnosti, SP - sidro predanosti, SI-sidro izziva, SŽS - sidro življenjskega stila 
SPREMEMBE KARIERNIH SIDER PRI POKLICIH

- Pri položaju direktorja oziroma menedžerja smo ugotovili dve spremembi. Oba menedžerja sta iz tehnično-funkcionalnega sidra prešla v menedžersko sidro.

- Pri poklicu vodje oddelka, vodje enote smo ugotovili tri spremembe, in sicer sta dva anketiranca spremenila karierno sidro iz menedžerskega $v$ sidro podjetniške ustvarjalnosti, en vodja pa je spremenil tehnično-

Tobela 3: Spremembe kariernih sider glede na delovno mesto/poklic

\begin{tabular}{|c|c|c|c|c|c|}
\hline & \multicolumn{2}{|c|}{ Sprememba kariernega sidra } & \multirow{2}{*}{ Skupaj } \\
\hline & & & NE & DA & \\
\hline \multirow{26}{*}{$\begin{array}{l}\text { Delovno } \\
\text { mesto leta } \\
2004\end{array}$} & \multirow{2}{*}{ direktor podjetja } & število & 28 & 2 & 30 \\
\hline & & v odstotkih & $9,3,3$ & 6,7 & 100,0 \\
\hline & \multirow{2}{*}{ vodja oddelka/enote } & število & 17 & 3 & 20 \\
\hline & & v odstotkih & 85,0 & 15,0 & 100,0 \\
\hline & \multirow{2}{*}{ tajnica/poslovna sekretarka } & število & 30 & 4 & 34 \\
\hline & & v odstotkih & 88,2 & 11,8 & 100,0 \\
\hline & \multirow{2}{*}{ organizator dela/organizacija dela } & število & 7 & 1 & 8 \\
\hline & & $\mathrm{v}$ odstotkih & 87,5 & 12,5 & 100,0 \\
\hline & \multirow{2}{*}{ pravna služba } & število & 11 & & 11 \\
\hline & & v odstotkih & 100,0 & & 100,0 \\
\hline & \multirow{2}{*}{ komercialist } & število & 3 & 1 & 4 \\
\hline & & v odstotkih & 75,0 & 25,0 & 100,0 \\
\hline & \multirow{2}{*}{ inženir } & število & 12 & & 12 \\
\hline & & $\mathrm{v}$ odstotkih & 100,0 & & 100,0 \\
\hline & \multirow{2}{*}{ ekonomist/finančni analitik } & število & 10 & 2 & 12 \\
\hline & & v odstotkih & 83,3 & 16,7 & 100,0 \\
\hline & \multirow{2}{*}{ kadrovski delavec } & število & 9 & 2 & 11 \\
\hline & & v odstotkih & 81,8 & 18,2 & 100,0 \\
\hline & \multirow{2}{*}{ zdravnik } & število & 5 & 1 & 6 \\
\hline & & $\mathrm{v}$ odstotkih & 83,3 & 16,7 & 100,0 \\
\hline & \multirow{2}{*}{ učitelj/profesor } & število & 10 & 1 & 11 \\
\hline & & v odstotkih & 90,9 & 9,1 & 100,0 \\
\hline & \multirow{2}{*}{ upravni delavec } & število & 25 & 1 & 26 \\
\hline & & v odstotkih & 96,2 & 3,8 & 100,0 \\
\hline & \multirow{2}{*}{ drugo } & število & 9 & 3 & 12 \\
\hline & & $\mathrm{v}$ odstotkih & 75,0 & 25,0 & 100,0 \\
\hline \multirow{2}{*}{\multicolumn{2}{|c|}{ Skupaj }} & število & 176 & 21 & 197 \\
\hline & & v odstotkih & 88,3 & 10,7 & 100,0 \\
\hline
\end{tabular}




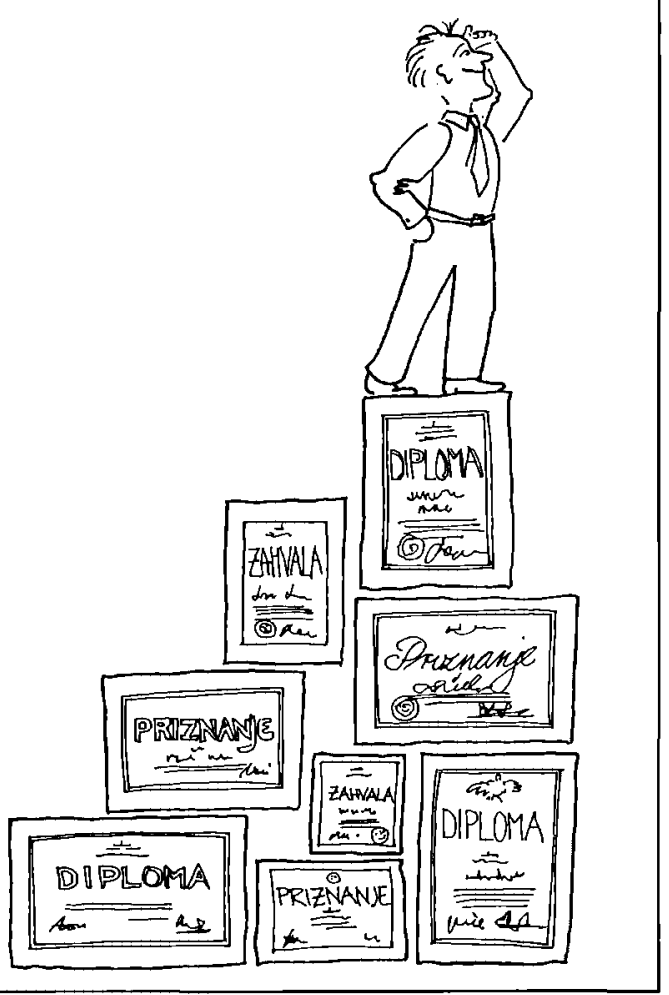

funkcionalno sidro v sidro samostojnosti in neodvisnosti.

- Pri poklicu tajnice oziroma poslovne sekretarke smo ugotovili štiri prehode, in sicer dva prehoda $j z$ sidra predanosti v sidro varnosti in stabilnosti, en prehod iz menedžerskega sidra $v$ sidro podjetniške ustvarjalnosti in en prehod iz sidra predanosti $v$ sidro podjetniške ustvarjalnosti.

- Pri poklicu organizator dela/organizacija dela smo ugotovili en prehod, in sicer iz sidra predanosti $v$ sidro varnosti in stabilnosti.

- Pri poklicu pravnik/pravna služba nismo ugotovili nobenega prehoda.
- Pri poklicu komercialista smo ugotovili en prehod, in sicer iz sidra izziva v sidro podjetniške ustvarjalnosti.

- Pri poklicu inženirja nismo ugotovili nobenega prehoda.

- Pri poklicu ekonomistalfinančnega analitika smo zaznali dva premika, in sicer premik iz sidra izziva v sidro podjetniške ustvarjalnosti in premik iz sidra samostojnosti in neodvisnosti v sidro življenjskega stila.

- Pri poklicu kadrovskega delavca smo ugotovili dva premika, in sicer prehod iz menedžerskega sidra $v$ tehnično-funkcionalno sidro.

- Pri poklicu zdravnika smo ugotovili en premik, in sicer iz sidra predanosti $v$ tehničnofunkcionalno sidro.

- Pri poklicu učitelja/profesorja smo ugotoviIi eno spremembo kariernega sidra, in sicer premik iz tebnično-funkcionalnega sidra $v$ sidro varnosti in stabilnosti.

- Pri poklicu upravnega delavca smo zaznali en premik iz sidra varnosti in stabilnosti $v$ sidro življenjskega stila.

- Pri devetih posameznikih, ki so iz navedenih poklicev prešli $v$ druge poklice, smo našteli še tri spremembe kariernih sider (drugi poklici, ki so se na novo pojavljali $\mathrm{v}$ odgovorih, so bili odnosi z javnostmi, urednik, tržni analitik, tržni svetovalec, komunikator, spletni urednik in skrbnik baz podatkov). Tako smo pri eni tajnici zaznali prehod iz kariernega sidra predanosti $v$ sidro izziva, $v$ istem obdobju je prešla iz poklica tajnice na delovno mesto oziroma $v$ poklic spletnega urednika. Tako je tudi posameznik iz poklica upravni delavec prešel v poklic odgovornega za odnose z javnostjo in obenem iz sidra varnosti in stabilnosti $v$ sidro življenjskega stila. Ugotovili smo še eno sočasno spremembo, in sicer je posameznik iz poklica organizator dela prešel na delovno mesto tržnega svetovalca in $v$ istem obdobju zamenjal tudi karierno sidro: iz sidra samostojnosti in neodvisnosti $v$ si- 
Iz naše raziskave izhaja, da se lahko karierno sidro razvije že zelo zgodaj, če je okolje dovolj spodbudno in če zagotavlja povratne informacije, lahko pa razvoj prevladujočega kariernega sidra traja tudi dije. Shein $(1986,1990)$ meni, da je 10 let delovnih izkušenj tista zgornja meja, ko vsakdo razvije svoje prevladujoče karierno sidro. Ko se karierno sidro oblikuje, postane razmeroma trajno notranje vodilo, saj Shein (prav tam) ni našel trdnih dokazov, da bi se v življenju spreminjalo.

dro izziva. Pri preostalih šestih oscbah, pri katerih smo ugotovili spremembo poklica, pa nismo ugotovili hkrati tudi spremembe kariernega sidra.

V vzorcu 197 anketirancev smo torej ugotovili 21 sprememb kariernih sider oziroma 10,7 odstotno spremenljivost kariernih sider. Vrednost hi-kvadrata oziroma Kulbackovega 21 . preizkusa $\left(\kappa^{2}=11,614, g=12, \dot{\alpha}=0,447\right)$ pokaže, da vrednost ni statistično pomembna in torej ne moremo najti statistično pomembne povezanosti med v raziskavi zajetimi 12 posameznimi poklici oziroma delovnimi mesti in spremembami kariernih sider. Spremembe kariernih sider so potekale neodvisno od vrste poklica in so povezane $z$ drugimi dejavniki.

\section{KDAJ SE KARIERNO SIDRO DOKONČNO IZOBLIKUIE?}

Strokovna literatura je navkljub raziskavam še vedno $v$ dilemi, ali posameznik razvije svoje prevladujoče karierno sidto šele takrat, ko ima iz svojega delovnega okolja dovolj povratnih informacij o sebi, o tem, kaj dela dobro, in o tem, kaj dela manj dobro in kje so njegovi talenti ter notranji potenciali, ali ga lahko razvije že mnogo prej, v obdobju odločanja za smer sekundarnega oz. terciarnega izobraževanja.

Da bi lahko odgovorili na vprašanje, ali se karierna sidra sodelujočih v naši raziskavi spreminjajo ali ne, in pritrdili Sheinovi ugotovitvi ali jo ovrgli tudi pri nas, smo naredili še analizo števila let skupne delovne dobe anketirancev (zajeli smo število delovnih let, ki so ga anketiranci navedli leta 2004) in jih povezali s spremembami kariernih sider, da bi ugotovili, ali število delovnih let vpliva na spremembo kariernega sidra ali ne. Pri tem smo anketirance razdelili na dve skupini. $V$ prvi so bili tisti, ki so imeli leta 2004 od 4 do 10 let delovne dobe, v drugi skupini pa tisti, ki so imeli leta 2004 od 11 do 38 let delovne dobe. Rezultati so razvidni iz tabele 4, pri čemer lahko takoj opazimo, da je do vseh 21 sprememb prišlo pri tistih posameznikih, ki smo jih razvrstili $v$ prvo skupino, torej $v$ skupino, ki je imela od 4 do 10 let delovne dobe.Vrednost hi-kva-

Tabela 4: Śtevilo let delovne dobe in spremembe kariernih sider

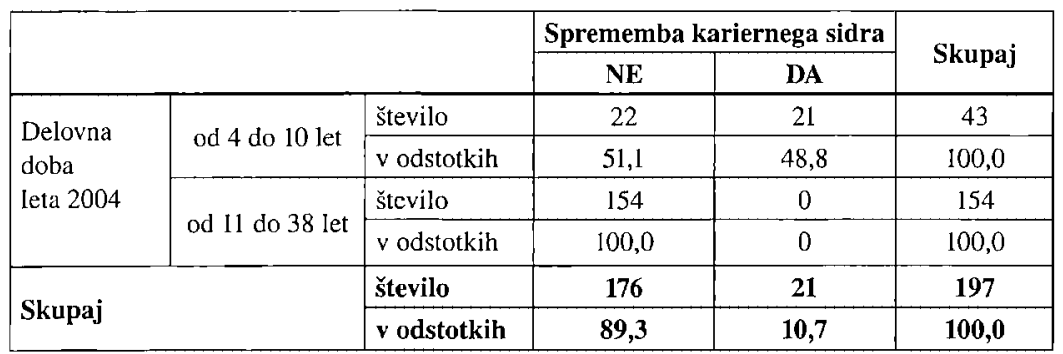


Tabela 5a: Razlogi xa menjovo poklica - statistika odgovorov

\begin{tabular}{|c|c|c|c|}
\hline \multicolumn{4}{|c|}{ Razlogi za menjavo poklica } \\
\hline & & število & v odstotkih \\
\hline \multirow{5}{*}{$\begin{array}{l}\text { Razlogi } \\
\text { za menjavo } \\
\text { poklica }\end{array}$} & večji zaslužek & 2 & 7,4 \\
\hline & osebne vrednote & 22 & 81,5 \\
\hline & geografski dejavniki & 1 & 3,7 \\
\hline & drugo & 2 & 7,4 \\
\hline & Skupaj & 27 & 100,0 \\
\hline
\end{tabular}

drata oziroma Kulbackovega 21. preizkusa $\left(\kappa^{2}=48.157, g=1, \dot{\alpha}=0,000\right)$ pokaže, da je vrednost statistično pomembna, in s tveganjem, manjšim od 0,1 odstotka, lahko trdimo, da je sprememba kariernega sidra povezana $s$ številom let delovne dobe. $V$ našem primeru lahko torej trdimo, da se karierno sidro lahko še spremeni v obdobju prvih desetih let delovne dobe, oziroma posameznik izčisti svoje karierno sidro $\mathrm{v}$ prvih desetih letih delovnih izkušenj. Ugotavljanje stopnje povezanosti s kontingenčnim koeficientom $(C=0,443)$ pokaže, da je povezanost med spremenljivkami $v$ vzorcu močna in statistično pomembna $(\dot{\alpha}=0,000)$.

$\mathrm{S}$ tem smo dodatno potrdili hipotezo oz. trditev, da se karierna sidra, ko so enkrat izoblikovana, ne spreminjajo več, in hkrati tudi

Posameznik iž̌isti svoje karierno sidro v prvih desetih letih delovnih izkušenj. trditev, da se karierna sidra izoblikujejo na podlagi povratnih informacij iz (delovnega) okolja. Nihče, ki je v štiriletnem obdobju spremenil karierno sidro, namreč ni imel več kot 10 let delovnih izkušenj. To tudi v slovenskem kulturnem okolju potrjuje hipotezo, da se karierna sidra oblikujejo najkasneje v prvih desetih letih delovnih izkušenj, nato pa se ne spreminjajo več. Tudi v naši raziskavi torej nismo našli zanesljivih dokazov, ki bi potrdili, da se karierna sidra, ko so enkrat trdno oblikovana, še spreminjajo. Pri večji razpršitvi vzorca bi bilo pričakovati, da bi naleteli na nekaj izjem, toda nizka stopnja sprememb kariernih sider ná vzorcu oziroma priložnostnem vzorcu nas prepričuje, da ni trdnih argumentov, ki bi dokazovali, da se karierna sidra spreminjajo, potem ko so enkrat izoblikovana.

\section{KARIERNA SIDRA IN MENJAVANJE POKLICEV}

Karierno sidro naj bi bilo torej trdno notranje vodilo, ki usmerja posameznika pri načrtovanju kariere in se mu ne bi odpovedal tudi $v$ hudih časih oziroma časih zmanjšanih možnosti za načrtovanje kariere. To vprašanje je vsekakor zanimivo, zato smo v naši raziskavi želeli pridobiti tudi podatke o vzrokih za menjavo poklica.

Ta podatek smo seveda lahko iskali le pri tistih, ki so v obdobju, ko je potekala raziskava, poklic zares zamenjali in sodelovali $v$ obeh raziskavah. Takšnih posameznikov smo našteli 27. Pri tem smo upoštevali le zamenjavo poklica, ne pa tudi zamenjave organizacije. Torej, če je posameznik prešel z delovnega mesta vodje oddelka na delovno mesto vodje oddelka v drugi organizaciji, tega nismo razumeli kot zamenjavo poklica. Kot take razumemo vse zamenjave, pri katerih se spremeni vsebina dela, recimo, če se tajnica odloči, da bo postala komercialistka, ali če se vodja oddelka odloči, da bo postal podjetnik, odprl torej lastno podjetje, ali če se upravni delavec odloči, da bo postal vodja projektov v zasebnem podjetju ...

Iz tabele 5a lahko vidimo, da je kar 81,5 odstotka anketirancev kot razlog zamenjave poklica navedlo osebne vrednote, 7,4 odstotka jih je navedlo večji zaslužek, 3,7 odstotka anketirancev jih je navajalo geografske dejavnike, 7,4 odstotka pa druge razloge, kot so stečaj organizacije, slab ugled podjetja ...

Razvidno je, da so dokaj prepričljiv razlog za zamenjavo poklica osebne vrednote, pri čemer so posamezniki povedali, da želijo ohraniti 
Tabela 5b: Zamenjave poklica v okviru posameznega prevladujočega kariernega sidra

\begin{tabular}{|c|c|c|c|c|c|c|c|}
\hline & & & \multicolumn{4}{|c|}{ Razlogi za menjavo poklica } & \multirow[b]{2}{*}{ Skupaj } \\
\hline & & & $\begin{array}{c}\text { večji } \\
\text { zaslužek }\end{array}$ & $\begin{array}{c}\text { osebne } \\
\text { vrednote }\end{array}$ & $\begin{array}{l}\text { geografski } \\
\text { dejavniki }\end{array}$ & drugo & \\
\hline \multirow{14}{*}{$\begin{array}{l}\text { Karierno } \\
\text { sidro } \\
2004\end{array}$} & \multirow{2}{*}{ MS } & število & & 3 & & & 3 \\
\hline & & v odstotkih & & 100,0 & & & 100,0 \\
\hline & \multirow{2}{*}{ TFS } & število & 1 & 2 & & & 3 \\
\hline & & v odstotkih & 33,3 & 66,7 & & & 100,0 \\
\hline & \multirow{2}{*}{ SSN } & število & & 1 & & & 1 \\
\hline & & $\mathrm{v}$ odstotkih & & 100,0 & & & 100,0 \\
\hline & \multirow{2}{*}{ SPU } & število & & 5 & 1 & 1 & 7 \\
\hline & & $v$ odstotkih & & 71,4 & 14,3 & 14,3 & 100,0 \\
\hline & \multirow{2}{*}{ SP } & štcvilo & & 2 & & & 2 \\
\hline & & v odstotkih & & 100,0 & & & 100,0 \\
\hline & \multirow{2}{*}{ SI } & število & 1 & 5 & & 1 & 7 \\
\hline & & v odstotkih & 14,3 & 71,4 & & 14,3 & 100,0 \\
\hline & \multirow{2}{*}{ SŽS } & število & & 4 & & & 4 \\
\hline & & v odstotkih & & 100,0 & & & 100,0 \\
\hline \multirow{2}{*}{\multicolumn{2}{|c|}{ Skupaj }} & število & 2 & 22 & 1 & 2 & 27 \\
\hline & & v odstotkih & 7,4 & 81,5 & 3,7 & 7,4 & 100,0 \\
\hline
\end{tabular}

svojo osebno integriteto, da jih motijo medosebni odnosi na delovnem mestu, da sledijo svoji notranji želji ..., da so končno spoznali, kaj hočejo v življenju ...

Pri tem nas je zanimalo tudi, ali obstaja povezanost med menjavo poklicev in obstoječimi kariernimi sidri. $S$ tem namenom smo naredili preizkus statistične pomembnosti med spremenljivkama menjava poklica in karierno sidro. Rezultati so prikazani v tabeli $5 b$.

Iz podatkov lahko ugotovimo, da so osebne vrednote botrovale zamenjavi poklica prav $v$ vseh sidrih, pri katerih je prišlo do zamenjave poklica.'

Vrednost hi-kvadrata oziroma Kulbackovega 21. preizkusa $\left(k^{2}=10.308, g=18, \dot{a}=0,921\right)$ pokaže, da vrednost ni statistično pomembna. To pomeni, da ne moremo najti statistično pomembnih povezav med razlogi za menjavo poklica in prevladujočimi kariernimi sidri.
Pravzaprav je večina anketiranih izrazila kot razlog za menjavo poklica osebne vrednote, kar prej dokazuje pomen osebnih vrednot ter s tem kariernih sider za izbiro poklica.

\section{GLAVNI MOTIVI ZA IZBIRO PRVEGA POKLICA VZDOLŽ KARIERNIH SIDER}

Ko smo udeležence spraševali po razlogu za zamenjavo poklica, nas je zanimalo tudi, kaj je botrovalo njihovi odločitvi za prvi poklic. $\mathrm{V}$ to raziskavo smo vključili le anketirance, $\mathrm{ki}$ so sodelovali v obeh raziskavah, torej je bilo $v$ vzorcu 197 oseb oseb, ki smo jih razdelili vzdolž prevladujočih kariernih sider in skušali identificirati glavni motiv, ki je botroval njihovi odločitvi za prvi poklic.

Iz tabele 6 je razvidno, da je večina, $\operatorname{kar} 68,9$ odstotka anketirancev, odgovorila, da je bil 
Tobela 6: Glavni motiv za izbiro prvega poklica glede na prevladujače karierno sidro

\begin{tabular}{|c|c|c|c|c|c|c|}
\hline & & & Glav & tiv za izbiro prve & lica & \\
\hline & & & zaslužek & $\begin{array}{l}\text { lastna predstava } \\
\text { o vsebini dela }\end{array}$ & drugo & Skupaj \\
\hline & TFS & število & 4 & 31 & 12 & 47 \\
\hline & 1Fs & v odstotkih & 8,5 & 66,0 & 25,5 & 100,0 \\
\hline & $M S$ & število & 15 & 18 & 1 & 34 \\
\hline & 1010 & v odstotkih & 44,1 & 52,9 & 2,9 & 100,0 \\
\hline & $\mathrm{SSN}$ & število & & 13 & 5 & 18 \\
\hline & SSN & v odstotkih & & 72,2 & 27,8 & 100,0 \\
\hline & CVS & število & 4 & 12 & 6 & 22 \\
\hline Karierno & $S \sqrt{S}$ & v odstotkih & 18,2 & 54,5 & 27,3 & 100,0 \\
\hline sidro 2004 & SDD & število & & 9 & 1 & 10 \\
\hline & SPU & v odstotkih & & 90,0 & 10,0 & 100,0 \\
\hline & SP & število & 1 & 28 & 5 & 34 \\
\hline & SF & v odstotkih & 2,9 & 82,4 & 14,7 & 100,0 \\
\hline & CI & število & 3 & 11 & 1 & 15 \\
\hline & SI & v odstotkih & 20,0 & 73,3 & 6,7 & 100,0 \\
\hline & šs & število & 1 & 13 & 2 & 16 \\
\hline & & v odstotkih & 6,3 & 81,3 & 12,5 & 100,0 \\
\hline & & število & 28 & 135 & 33 & 196 \\
\hline Skupaj & & v odstotkih & 14,3 & 68,9 & 16,8 & 100,0 \\
\hline
\end{tabular}

glavni motiv za izbiro prvega poklica lastna predstava o vsebini dela, 14,3 odstotka se jih je $z$ odločitvijo za izbiro prvega poklica nadejalo visokega zaslužka, pri 16,8 odstot-

\section{Motiv za izbiro prvega poklica je povezan s prevla- dujočim kariernim sidrom.}

ka anketirancev pa so botrovali drugi vzroki, recimo geografska bližina, družinsko podjetje ... Še najbolj so si visokega zaslužka obetali posamezniki z menedžerskim sidrom. Kar 44,1 odstotka jih je za glavni motiv navedlo visok zaslužek. Vrednost hikvadrata oziroma Kulbackovega 21. preizkusa $\left(k^{2}=44,763 a, g=14, \dot{a}=0,000\right)$ pokaže, da je vrednost statistično pomembna, in s tveganjem, manjšim od 0,1 odstotka, lahko trdimo, da je motiv za izbiro prvega poklica povezan s prevladujočim kariernim sidrom oziroma nanj karierno sidro močno vpliva. Ugotavljanje stopnje povezanosti na podlagi kontingenčnega koeficienta $(C=0,431)$ pokaže, da je povezanost med spremenljivka$m i v$ vzorcu močna in statistično pomembna $(\dot{\alpha}=0,000)$.

\section{NAČRTOVANJE IZOBRAŽEVANJA IN KARIERNA SIDRA}

V prispevku zastopamo stališče, da je razvoj kariere mogoče enačiti $z$ razvojem izobraževalne poti. Prav zato smo se po tem, ko smo se prepričali, da so karierna sidra, ko so 
Tabela 7: Vpliv na odločitev za izbiro smeri formalnega izobraževanja glede na prevladujoče karierno sidro

\begin{tabular}{|c|c|c|c|c|c|c|c|}
\hline & \multicolumn{4}{|c|}{ Vpliv na odločitev o izbiri poklica } & \multirow[b]{2}{*}{ Skupaj } \\
\hline & & & $\begin{array}{l}\text { lastni } \\
\text { zgodnji } \\
\text { izbor }\end{array}$ & $\begin{array}{c}\text { želja } \\
\text { staršev }\end{array}$ & $\begin{array}{l}\text { finančne } \\
\text { možnosti } \\
\text { oziroma } \\
\text { omejitve }\end{array}$ & $\begin{array}{c}\text { odločitve } \\
\text { prijateljev/ } \\
\text { znancev }\end{array}$ & \\
\hline \multirow{16}{*}{$\begin{array}{l}\text { Karierno } \\
\text { sidro } 2004\end{array}$} & \multirow{2}{*}{ TFS } & število & 42 & 2 & 3 & & 47 \\
\hline & & v odstotkih & 89,4 & 4,3 & 6,4 & & 100,0 \\
\hline & \multirow{2}{*}{ MS } & število & 25 & 7 & 1 & 1 & 34 \\
\hline & & $v$ odstotkih & 73,5 & 20,6 & 2,9 & 2,9 & 100,0 \\
\hline & \multirow{2}{*}{ SSN } & število & 16 & 2 & 1 & & 19 \\
\hline & & v odstotkih & 84,2 & 10,5 & 5,3 & & 100,0 \\
\hline & \multirow{2}{*}{ SVS } & število & 9 & 7 & 4 & 2 & 22 \\
\hline & & v odstotkih & 40,9 & 31,8 & 18,2 & 9,1 & 100,0 \\
\hline & \multirow{2}{*}{ SPU } & število & 8 & 1 & 1 & & 10 \\
\hline & & v odstotkih & 80,0 & 10,0 & 10,0 & & 100,0 \\
\hline & \multirow{2}{*}{ SP } & število & 18 & 7 & 2 & 7 & 34 \\
\hline & & v odstotkih & 52,9 & 20,6 & 5,9 & 20,6 & 100,0 \\
\hline & \multirow{2}{*}{ SI } & število & 5 & 2 & 3 & 5 & 15 \\
\hline & & v odstotkih & 33,3 & 13,3 & 20,0 & 33,3 & 100,0 \\
\hline & \multirow{2}{*}{ Š̌S } & število & 10 & & 2 & 4 & 16 \\
\hline & & v odstotkih & 62,5 & & 12,5 & 25,0 & 100,0 \\
\hline \multirow{2}{*}{\multicolumn{2}{|c|}{ Skupaj }} & Število & 133 & 28 & 17 & 19 & 197 \\
\hline & & v odstotkih & 67,5 & 14,2 & 8,6 & 9,6 & 100,0 \\
\hline
\end{tabular}

enkrat oblikovana, razmeroma trajna notranja usmeritev posameznika, ki temelji na njegovih osebnih vrednotah, $v$ raziskavi lotili še enega vprašanja, in sicer, kako posamezniki $\mathrm{z}$ različnimi kariernimi sidri načrtujejo izobraževanje.

V raziskavi, ki smo jo izvedli leta 2004, smo pri udeležencih torej najprej analizirali prevladujoče karierno sidro, obenem pa smo jim zastavili tudi vrsto vprašanj o tem, kako načrtujejo oziroma so načrtovali izobraževanje. $Z$ vprašalnikom smo želeli dobiti vpogled $\checkmark$ načrtovanje formalnega in funkcionalnega oziroma neformalnega izobraževanja ter usposabljanja v zvezi z delom. Želeli smo pri- dobiti prerez izobraževalnih biografij glede na posamezno karierno sidro, da bi lahko tudi glede na prevladujoče karierno sidro sklepali oziroma predvideli prihodnjo izobraževalno pot posameznika. Pri tem bomo torej iskali podobnosti in razlike pri načrtovanju izobraževanja glede na prevladujočc karierno sidro.

\section{NAČRTOVANJE FORMALNEGA IZOBRAŽEVANIA}

Najprej nas je zanimalo, kakšen vpliv so imeli na posameznike $\mathrm{z}$ različnimi kariernimi sidri posamezni dejavniki pri prvi izbiri smeri formalnega študija. Rezultati so prikazani v tabe- 
Tabela 8: Menjava smeri formalnega izobraževanja med šłudijem glede na prevladujoče karierno sidro

\begin{tabular}{|c|c|c|c|c|c|c|}
\hline & \multicolumn{3}{|c|}{ Menjava smeri formalnega izobraževanja } & \multirow{2}{*}{ Skupaj } \\
\hline & & & nikoli & enkrat & večkrat & \\
\hline \multirow{16}{*}{$\begin{array}{l}\text { Karierno } \\
\text { sidro } 2004\end{array}$} & \multirow{2}{*}{ TFS } & število & 39 & 8 & & 47 \\
\hline & & v odstotkih & 83,0 & 17,0 & & 100,0 \\
\hline & \multirow{2}{*}{ MS } & število & 28 & 5 & 1 & 34 \\
\hline & & v odstotkih & 82,4 & 14,7 & 2,9 & 100,0 \\
\hline & \multirow{2}{*}{ SSN } & število & 15 & 2 & 2 & 19 \\
\hline & & v odstotkih & 78,9 & 10,5 & 10,5 & 100,0 \\
\hline & \multirow{2}{*}{ SVS } & število & 20 & 2 & & 22 \\
\hline & & v odstotkih & 90,9 & 9,1 & & 100,0 \\
\hline & \multirow{2}{*}{ SPU } & število & 6 & 4 & & 10 \\
\hline & & v odstotkih & 60,0 & 40,0 & & 100,0 \\
\hline & \multirow{2}{*}{ SP } & število & 30 & 3 & 1 & 34 \\
\hline & & $\mathrm{v}$ odstotkih & 88,2 & 8,8 & 2,9 & 100,0 \\
\hline & \multirow{2}{*}{ SI } & število & 7 & 5 & 3 & 15 \\
\hline & & v odstotkih & 46,7 & 33,3 & 20,0 & 100,0 \\
\hline & \multirow{2}{*}{ SŽS } & število & 11 & 2 & 1 & 14 \\
\hline & & v odstotkih & 78,6 & 14,3 & 7,1 & 100,0 \\
\hline \multirow{2}{*}{\multicolumn{2}{|c|}{ Skupaj }} & število & 156 & 31 & 8 & 195 \\
\hline & & v odstotkih & 80,0 & 15,9 & 4,1 & 100,0 \\
\hline
\end{tabular}

li 7. Pri vseh kariernih sidrih smo kot osrednji motiv ugotovili dejavnik zgodnja lastna izbira poklica. Najbolj izstopa tehnično-funkcionalno sidro, pri katerem je 89,4 odstotka anketirancev odgovorilo, da je bil to Tudi izbira smeri formalnega izobraževanja je povezana s kariernim sidrom. glavni motiv, najmanj, tj. 33,3 odstotka anketirancev s sidrom izziva, je lastno zgodnjo izbiro poklica izbralo kot glavni motiv za izbiro formalne smeri izobraževanja. Vpliv staršev je najočitnejši pri kariernem sidru varnosti in stabilnosti ( 31,8 odstotka) in najmanj pri življenjskem stilu ( 0 odstotkov). Finančne omejitve so bile najpogostejše pri kariernem sidru izziva (20 odstotkov) in najmanj pri menedžerskem kariernem sidru $(2,9$ odstotka). Odločitve so- šolcev in prijateljev so najbolj vplivale na odločitve posameznikov s kariernim sidrom izziva (33,3 odstotka), najmanj ozjroma nič pa na posameznike s tehnično-funkcionalnim sidrom, sidrom samostojnosti in neodvisnosti ter sidrom podjetniške ustvarjalnosti.

Vrednost hi-kvadrata oziroma Kulbackovega 21. preizkusa $\left(k^{2}=60,235, g=21, \dot{\alpha}=0,000\right)$ pokaže, da je vrednost statistično pomembna, in s tveganjem, manjšim od 0,1 odstotka, lahko trdimo, da je vpliv na izbiro formalne smeri šolanja prav tako povezan s prevladujočim kariernim sidrom, oziroma so posamezniki s posameznimi prevladujočimi kariernimi sidri zapadli določenim vplivom, ko so se odločali za smer formalnega izobraževanja. Ugotavljanje stopnje povezanosti med spremenljivkama, torej vplivom na izbiro formalne smeri 
Tabela 9: Raxlogi za menjavo smeri formalnega izobraževanja med študijem glede na prevladujoče karierno sidro

\begin{tabular}{|c|c|c|c|c|c|c|}
\hline & & & \multicolumn{3}{|c|}{$\begin{array}{l}\text { Razlogi za menjavo smeri } \\
\text { formalnega izobraževanja }\end{array}$} & \multirow{2}{*}{ Skupaj } \\
\hline & & & $\begin{array}{c}\text { prevlada drugih } \\
\text { interesov }\end{array}$ & $\begin{array}{c}\text { neuspeh } \\
\text { pri študiju }\end{array}$ & $\begin{array}{c}\text { boljša možnost } \\
\text { za zaposlitev }\end{array}$ & \\
\hline \multirow{16}{*}{$\begin{array}{l}\text { Karierno } \\
\text { sidro } 2004\end{array}$} & \multirow{2}{*}{ TFS } & število & 3 & 3 & 2 & 8 \\
\hline & & v odstotkih & 37,5 & 37,5 & 25,0 & 100,0 \\
\hline & \multirow{2}{*}{ MS } & število & 6 & & & 6 \\
\hline & & v odstotkih & 100,0 & & & 100,0 \\
\hline & \multirow{2}{*}{ SSN } & število & 3 & & 1 & 4 \\
\hline & & v odstotkih & 75,0 & & 25,0 & 100,0 \\
\hline & \multirow{2}{*}{ SVS } & število & & & 2 & 2 \\
\hline & & v odstotkih & & & 100,0 & 100,0 \\
\hline & \multirow{2}{*}{ SPU } & število & 3 & 1 & & 4 \\
\hline & & v odstotkih & 75,0 & 25,0 & & 100,0 \\
\hline & \multirow{2}{*}{$\mathrm{SP}$} & Število & 2 & 1 & 1 & 4 \\
\hline & & v odstotkih & 50,0 & 25,0 & 25,0 & 100,0 \\
\hline & \multirow{2}{*}{ SI } & število & 6 & 1 & 1 & 8 \\
\hline & & v odstotkih & 75,0 & 12,5 & 12,5 & 100,0 \\
\hline & \multirow{2}{*}{ SŽS } & število & 1 & 2 & & 3 \\
\hline & & v odstotkih & 33,3 & 66,7 & & 100,0 \\
\hline \multirow{2}{*}{ Skupaj } & & število & 24 & 8 & 7 & 39 \\
\hline & & v odstotkih & 61,5 & 20,5 & 18 & 100,0 \\
\hline
\end{tabular}

šolanja in kariernim sidrom, na podlagi kontingenčnega koeficienta $(\mathrm{C}=0,470)$ pokaže, da je povezanost med spremenljivkami $v$ vzorcu srednje močna in statistično pomembna $(\dot{a}=0,000)$.

Anketirance smo tudi povprašali, ali so si med formalnim študijern premislili in zamenjali smer ter kaj je bil razlog za zamenjavo smeri študija. $\mathrm{V}$ analizo razlogov za menjavo smeri formalnega izobraževanja smo vključili le tiste anketirance, ki so enkrat ali večkrat menjali smer formalnega izobraževanja, in jih povprašali po razlogih zanje. Odgovori so navedeni $v$ tabelah 8 in 9.

Iz zbranih podatkov lahko vidimo, da 80 odstotkov anketirancev ni zamenjalo smeri for- malnega izobraževanja, 20 odstotkov pa jih je smer zamenjalo, med njimi 15,9 odstotka enkrat, 4,1 odstotka pa večkrat. Vrednost hikvadrata oziroma Kulbackovega 21. preizkusa ( $\left(\kappa^{2}=23,982, g=14, \dot{a}=0,046\right)$ pokaže, da je vrednost statistično pomembna, in s tveganjem, manjšim od 0,1 odstotka, lahko trdimo, da je menjava smeri formalnega šolanja prav tako povezana s prevladujočim kariernim sidrom, oziroma da karierno sidro posameznika vpliva tudi na odločitev glede menjave smeri formalnega šolanja. U gotavljanje stopnje povezanosti med spreme nljivkama na podlagi kontingenčnega koeficienta $(C=0,348)$ pokaže, da je povezanost rmed spremenljivkami v vzorcu srednje veli ka in statistično 
Tabela 10: Dodatno izobraževanje v domačem okolju med formalnim izobraževanjem glede na prevladujoče karierno sidro

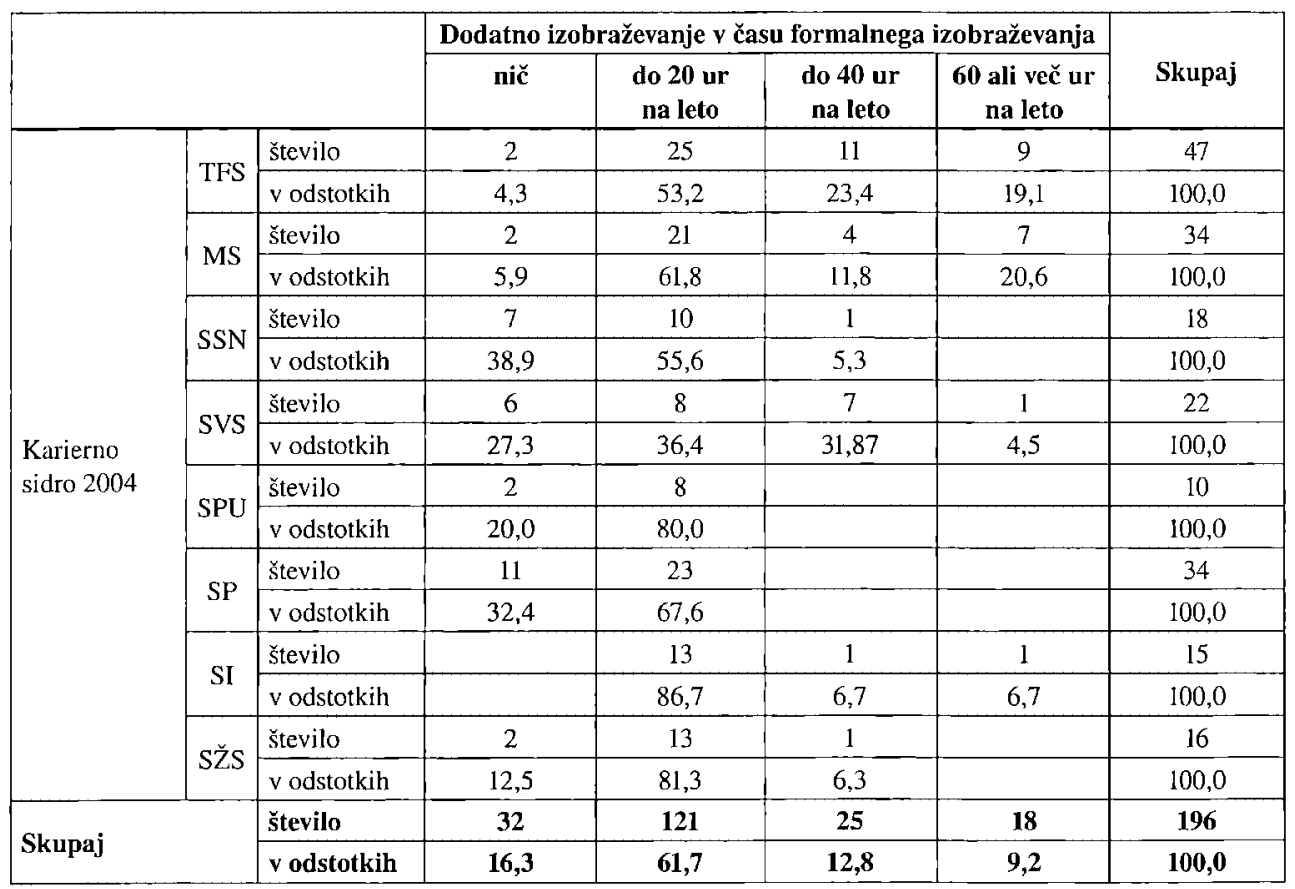

pomembna $(\alpha=0,020)$. Seveda nas je pri posameznikih, ki so zamenjali smer formalnega izobraževanja, zanimal tudi razlog, zakaj so zamenjali smer. Izbor možnih odgovorov smo zaradi preglednosti omejili na tri (glej tabelo 9). Prevlado drugih interesov kot razlog za zamenjavo študija je v odstotkih navedlo največ posameznikov s tehnično-funkcionalnim sidrom, sidrom samostojnosti in neodvisnosti, sidrom varnosti in stabilnosti ter sidrom izziva (75 odstotkov). Neuspeh pri študiju pa so največkrat kot razlog za zamenjavo smeri formalnega izobraževanja navajali posamezniki s sidrom življenjskega stila, 100 odstotkov posameznikov s sidrom varnosti in stabilnosti pa se je za zamenjavo študija odločilo zaradi boljših zaposlitvenih možnosti. Večina, torej kar 61,5 odstotka, se je za zamenjavo smeri formalnega izobraževanja odločila zaradi drugih interesov.

Vrednost hi-kvadrata oziroma Kulbackovega 21. preizkusa ( $\aleph^{2}=19,455, g=14, \dot{\alpha}=0,148$ ) pokaže, da vrednost ni statistično pomembna. To pomeni, da naštete vzroke za menjavo smeri študija ne moremo zanesljivo povezati s prevladujočim kariernim sidrom.

\section{PRIDOBIVANJE DODATNIH UČNIH IZKUŠENI MED FORMALNIM IZOBRAŽEVANJEM}

Anketirance smo tudi vprašali, ali so si med potekom formalnega izobraževanja tudi dodatno pridobivali znanje, torej ne le po pred- 
Tabela 11: Pridobivanje izkušenj x delovanjem v prostovoljnih organizacijah in društvih glede na prevladujoče karierno sidro

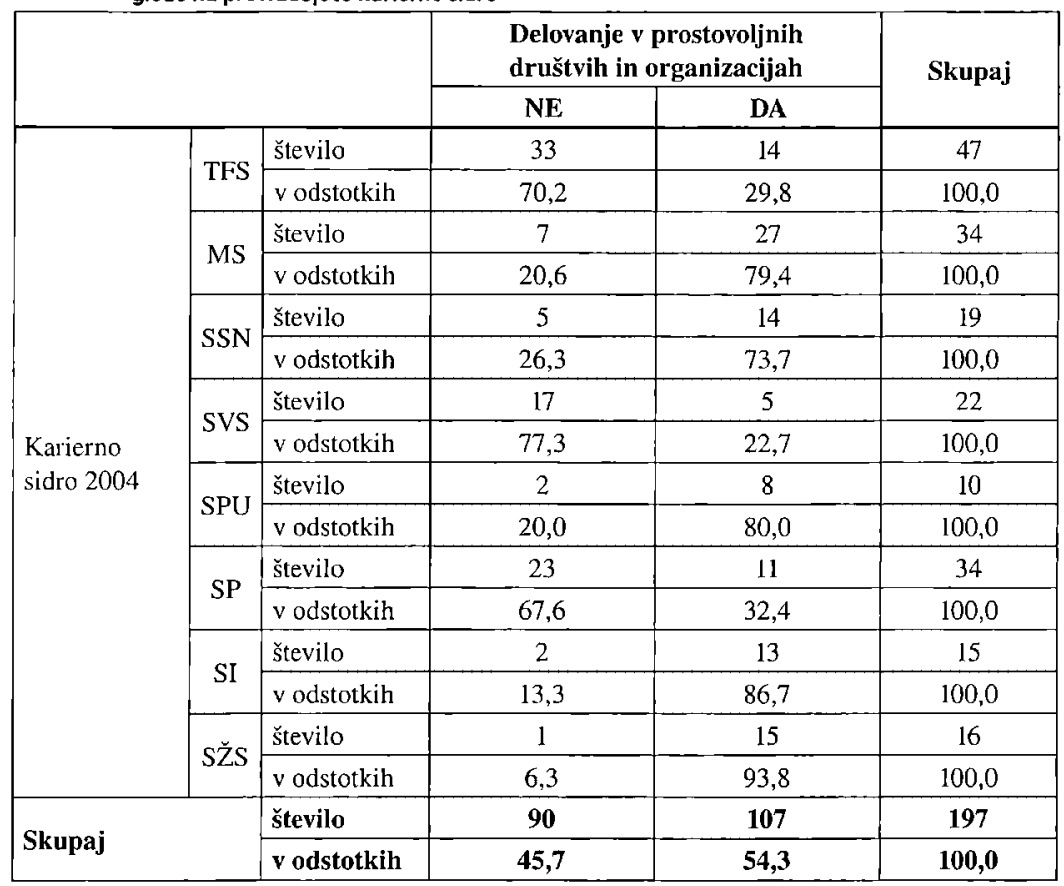

pisanem programu študija. Pri tem smo jim dali več možnosti, in sicer so se anketiranci opredelili za obseg dodatnega izobraževanja po urah v letu dni. Na voljo so imeli odgovore: nič ur, do 20 ur, do 40 ur oziroma 60 ur ali več. Pri tem smo skušali ugotoviti, ali obstajajo podobnosti oziroma razlike pri količini dodatnega izobraževanja glede na posamezno karierno sidro.

Le 16,3 odstotka anketirancev se med formalnim izobraževanjem ni dodatno izobraževalo. Več kot polovica oziroma 61,7 odstotka vseh anketirancev se je torej dodatno izobraževalo do 20 ur na leto, 12,8 anketirancev se je izobraževalo do 40 ur na leto, 9,2 odstotka anketirancev pa že več kot 60 ur na leto že med formalnim izobraževanjem. Vrednost hi-kvadrata oziroma Kulbackovega 21. preizkusa $\left(\kappa^{2}=73,546, g=21, \dot{\alpha}=0,000\right)$ kaže, da je vrednost statistično pomembna, in $s$ tveganjem, manjšim od 0,1 odstotka, lahko trdimo, da je prevladujoče karierno sidro povezano $\mathrm{z}$ dodatnim izobraževanjem med formalnim izobraževanjem. Ugotavljanje stopnje povezanosti med spremenljivkama na podlagi kontingenčnega koeficienta ( $\mathrm{C}=0,494)$ pokaže, da je povezanost med spremenljivkami v vzorcu močna in statistično pomembna $(\dot{\alpha}=0,000)$.

Pomemben vir pridobivanja znanja in izkušenj ter vpogledov za načrtovanje kariere je tudi delovanje posameznikov $\mathrm{v}$ društvih oziroma prostovoljnih organizacijah. Veliko posameznikov se je kalilo $\mathrm{z}$ delovanjem $\mathrm{v}$ tovrstnih 
Tabela 12: Izobraževanje in pridobivanje izkušenj v rujini med rednim izobraževanjem glede na prevladujoče karierno sidro

\begin{tabular}{|c|c|c|c|c|c|c|c|}
\hline & \multicolumn{4}{|c|}{ Pridobivanje znanj in izkušenj $\mathrm{v}$ tujini } & \multirow[b]{2}{*}{ Skupaj } \\
\hline & & & $\begin{array}{c}\text { Ne, } \\
\text { popolnoma } \\
\text { sem se posvetil } \\
\text { študiju doma. }\end{array}$ & $\begin{array}{c}\text { Da, } \\
\text { del časa sem se } \\
\text { izobraževal } \\
\text { tudi v tujini. }\end{array}$ & $\begin{array}{c}\text { Da, } \\
\text { izkušnje sem } \\
\text { pridobival } \\
\text { z delom v } \\
\text { tujini. } \\
\end{array}$ & $\begin{array}{c}\mathrm{DA}, \\
\text { izobraževal in } \\
\text { pridobival } \\
\text { sem izkušnje z } \\
\text { delom v tujini. }\end{array}$ & \\
\hline \multirow{16}{*}{$\begin{array}{l}\text { Karierno } \\
\text { sidro } \\
2004\end{array}$} & \multirow{2}{*}{ TFS } & število & 38 & 4 & 3 & 2 & 47 \\
\hline & & v odstotkih & 80,9 & 8,5 & 6,4 & 4,3 & 100,0 \\
\hline & \multirow{2}{*}{ MS } & Število & 21 & 6 & 3 & 4 & 34 \\
\hline & & v odstotkih & 61,8 & 17,6 & 8,8 & 11,8 & 100,0 \\
\hline & \multirow{2}{*}{ SSN } & število & 15 & 1 & 3 & & 19 \\
\hline & & v odstotkih & 78,9 & 5,3 & 15,8 & & 100,0 \\
\hline & \multirow{2}{*}{ SVS } & število & 20 & 2 & & & 22 \\
\hline & & v odstotkih & 90,9 & 9,1 & & & 100,0 \\
\hline & \multirow{2}{*}{ SPU } & Število & 4 & 1 & 3 & 2 & 10 \\
\hline & & v odstotkih & 40,0 & 10,0 & 30,0 & 20,0 & 100,0 \\
\hline & \multirow{2}{*}{ SP } & število & 30 & 2 & & 2 & 34 \\
\hline & & v odstotkih & 88,2 & 5,9 & & 5,9 & 100,0 \\
\hline & \multirow{2}{*}{ SI } & število & 3 & 5 & 5 & 2 & 15 \\
\hline & & v odstotkih & 20,0 & 33,3 & 33,3 & 13,3 & 100,0 \\
\hline & \multirow{2}{*}{ SŽS } & stevilo & 12 & 3 & & & 15 \\
\hline & & v odstotkih & 80,0 & 20,0 & & & 100,0 \\
\hline \multirow{2}{*}{\multicolumn{2}{|c|}{ Skupaj }} & število & 143 & 24 & 17 & 12 & 196 \\
\hline & & $v$ odstotkih & 73,0 & 12,2 & 8,7 & 6,1 & 100,0 \\
\hline
\end{tabular}

ustanovah oziroma združenjih, zato smo udeležencern raziskave zastavili tudi vprašanje, ali so med rednim izobraževanjem delovali

Karierno sidro vpliva tudi na izbiro in intenziteto učne poti. $\mathrm{v}$ prostovoljnih in poklicnih združenjih oziroma društvih, pri čemer je bilo njihovo delo prostovoljno oziroma zanj niso prejeli denarnega plačila.

Podatki kažejo, da se je za delovanje $v$ prostovoljnih društvih in organizacijah odločilo 54,3 odstotka anketirancev, od tega največ posameznikov s sidrom življenjskega stila ( 93,8 odstotka) in najmanj s sidrom varnosti ter stabilnosti $(22,7$ odstotka). Vrednost hi-kvadrata oziroma Kulbackovega 21. preizkusa $\left(\kappa^{2}=57,366 \mathrm{a}, \mathrm{g}=7\right.$, $\dot{a}=0,000$ ) pokaže, da je vrednost statistično pomembna, in s tveganjem, manjusim od 0,1 odstotka, lahko trdimo, da je prevladujoče karierno sidro povezano $\mathrm{z}$ delovanjem $\mathrm{v}$ prostovoljnih društvih in organizacijah kot virom dodatnega izobraževanja in pridobivanja učnih izkušenj med formalnim izobraževanjem. Ugotavljanje stopnje povezanosti med spremenljivkama na podlagi kontingenčnega koeficienta $(C=0,475)$ pokaže, da je povezanost med spremenljivkami v vzorcu srednje močna in statistično pomembna $(\dot{\alpha}=0,000)$. 
Pri načrtovanju izobraževanja nas je tudi zanimalo, ali so se anketiranci med potekom formalnega študija izobraževali in pridobivali znanje $v$ tujini. Ali so se šolali delno $v$ tujini in ali so delali $v$ tujini ter si tako pridobivali izkušnje? Znova smo ugotav]jali morebitne razlike med kariernimi sidri. Rezultati so prikazani tabeli 12.

Vidimo, da je večina anketirancev študirala doma, takih je bilo kar 73 odstotkov, 12,2 odstotka se jih je delno izobraževalo $v$ tuji$n i$, izkušnje $z$ delom si je $v$ tujini pridobivalo 8,7 odstotka oseb, delalo in izobraževalo $v$ tujini pa se je vsega skupaj 12 posameznikov oziroma 6,1 odstotka. Vrednost hi-kvadrata oziroma Kulbackovega 21. preizkusa $\left(\mathrm{K}^{2}=55,459, \mathrm{~g}=21, \dot{\alpha}=0,000\right)$ pokaže, da je vrednost statistično pomembna, in s tveganjem, manjšim od 0,1 odstotka, lahko trdimo, da je prevladujoče karierno sidro povezano tudi $z$ obsegom in intenziteto izobraževanja ter pridobivanja izkušenj v tujini med formalnim izobraževanjem. Ugotavljanje stopnje povezanosti med spremenljivkama na podlagi kontingenčnega koeficienta $(C=0,462)$ pokaže, da je povezanost med spremenljivkami v vzorcu močna in statistično pomembna ( $\dot{\alpha}=0,000$ ).

Z vsemi temi preizkusi smo potrdili tudi hipotezo oz. trditev, da med posamezniki z enakimi kariernimi sidri lahko najdemo podobnosti pri načrtovanju izobraževanja. Več kot očitno je, da lahko sledimo različnim vzorcem načrtovanja izobraževalne poti glede na prevladujoče karierno sidro.

\section{VPLIV MOŽNOSTI IZOBRAŽEVAN]A NA IZBIRO ORGANIZACIJE}

Zakaj se ljudje odločajo za določeno organizacijo ob razmeroma enakih materialnih nagradah, je vprašanje, ki je že vrsto let izziv organizacijam in kadrovskim strokovnjakom po vsem svetu. Danes poteka globalna tekma

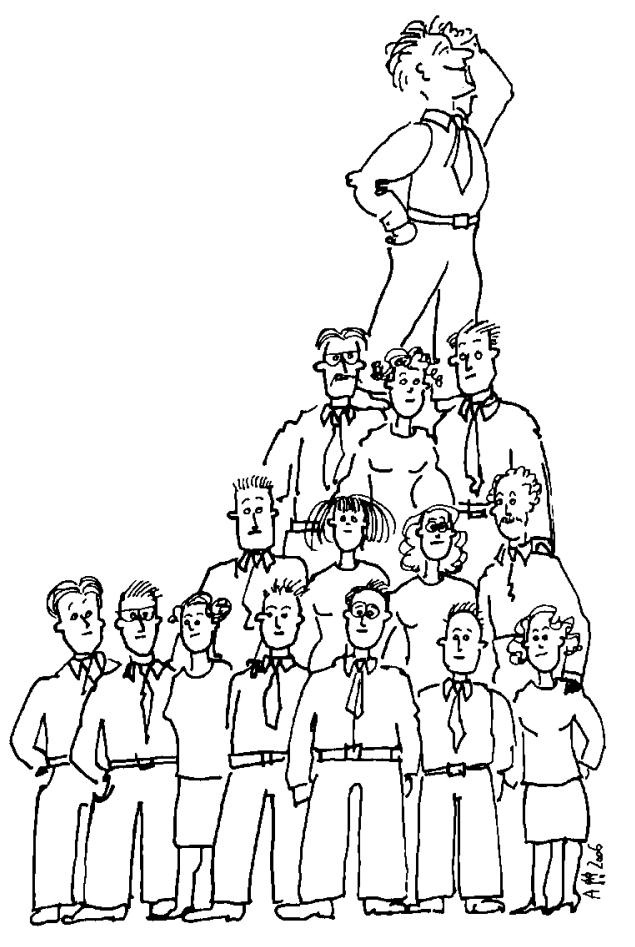

$v$ »lovu na talente jejo z znanjem, tekmujejo za najboljšse kadre, obenem pa ponujajo tudi izjemne možnosti za izobraževanje. Tako na eni strani postaja znanje vse bolj cenjen in konkurenčen vir posameznika pri iskanju zaposlitve, po drugi strani pa sta možnost in skrb za izobraževanje, ki ga ponujajo nekatere organizacije, magnet za nadarjene kadre.

V naši raziskavi smo z zbranimi podatki lahko dobili globji uvid tudi $v$ to dilemo oziroma področje. Vse udeležence v raziskavi smo prosili, da se skušajo spomniti, kakšen pomen so dajali izobraževanju povsem na začetku poklicne poti. Prosili smo jih, naj ocenijo po- 
Tabela 13: Vpliv mox̌nosti izobraževanja na izbiro organizocije

\begin{tabular}{|c|c|c|c|c|c|c|c|c|}
\hline & \multicolumn{5}{|c|}{ Pomen možnosti izobraževanja na izbiro organizacije } & \multirow[b]{2}{*}{ Skupaj } \\
\hline & & & $\begin{array}{l}\text { generacijska } \\
\text { struktura }\end{array}$ & $\begin{array}{l}\text { medosebni } \\
\text { odnosi }\end{array}$ & $\begin{array}{c}\text { možnost izo- } \\
\text { braževanja }\end{array}$ & $\begin{array}{c}\text { geografska } \\
\text { bližina }\end{array}$ & $\begin{array}{c}\text { ugled orga- } \\
\text { nizacije } v \\
\text { širši javnosti }\end{array}$ & \\
\hline \multirow{16}{*}{$\begin{array}{l}\text { Karierno } \\
\text { sidro } \\
2004\end{array}$} & \multirow{2}{*}{ TFS } & število & 10 & 7 & 19 & 6 & 5 & 47 \\
\hline & & $v$ odstotkih & 21,3 & 14,9 & 40,4 & 12,8 & 10,6 & 100,0 \\
\hline & \multirow{2}{*}{ MS } & število & 3 & 8 & 8 & & 15 & 34 \\
\hline & & v odstotkih & 8,8 & 23,5 & 23,5 & & 44,1 & 100,0 \\
\hline & \multirow{2}{*}{ SSN } & število & & 9 & 3 & 1 & 6 & 19 \\
\hline & & v odstotkih & & 47,4 & 15,8 & 5,3 & 31,6 & 100,0 \\
\hline & \multirow{2}{*}{ SVS } & \begin{tabular}{|l|} 
število \\
\end{tabular} & 2 & 5 & 5 & 2 & 8 & 22 \\
\hline & & v odstotkih & 9,1 & 22,7 & 22,7 & 9,1 & 36,4 & 100,0 \\
\hline & \multirow{2}{*}{ SPU } & \begin{tabular}{|l|} 
Število \\
\end{tabular} & 1 & 4 & 5 & & & 10 \\
\hline & & v odstotkih & 10,0 & 40,0 & 50,0 & & & 100,0 \\
\hline & \multirow{2}{*}{ SP } & število & 2 & 20 & 9 & 2 & 1 & 34 \\
\hline & & v odstotkih & 5,9 & 58,8 & 26,5 & 5,9 & 2,9 & 100,0 \\
\hline & \multirow{2}{*}{ SI } & število & & 5 & 8 & & 2 & 15 \\
\hline & & v odstotkih & & 33,3 & 53,3 & & 13,3 & 100,0 \\
\hline & \multirow{2}{*}{ SŽS } & število & 2 & 8 & 3 & 1 & 1 & 15 \\
\hline & & v odstotkih & 13,3 & 53,3 & 20,0 & 6,7 & 6,7 & 100,0 \\
\hline \multirow{2}{*}{\multicolumn{2}{|c|}{ Skupaj }} & število & 20 & 66 & 60 & 12 & 38 & 196 \\
\hline & & v odstotkih & 10,2 & 33,7 & 30,6 & 6,1 & 19,4 & 100,0 \\
\hline
\end{tabular}

men možnosti izobraževanja v organizaciji in vpliv, ki ga je ta možnost imela na izbiro organizacije. Anketiranci so odgovarjali tako, da so razvrstili dano možnost izobraževanja med še štirimi pomembnimi dejavniki izbire motivacijskega delovnega okolja (generacijska struktura, medosebni odnosi, geografska bližina in ugled organizacije $v$ širši javnosti). Namerno smo pri tem vprašanju izpustili motivacijski dejavnik »višja plača«, ker smo se želeli izogniti prevladujočemu vplivu materialnih nagrad. Pri tem je ocena 1 pomenila največji vpliv, 5 pa najmanjši vpliv. V tabeli 13 so prikazani odgovori anketirancev $z$ namenom, da bi znova ugotovili razlike ali podobnosti med posamezniki $z$ različnimi kariernimi si- dri. Kot je razvidno iz odgovorov, je največ (33,7 odstotka) anketirancev izbralo medosebne odnose, toda tesno za njimi se uvršča prav možnost izobraževanja, ki jo je kot glavni motiv izbralo kar 30,6 odstotka anketirancev. Pri primerjanju odgovorov pri posameznikih $\mathrm{z}$ različnimi kariernimi sidri je razvidno, da je možnost izobraževanja kot najpomembnejši vpliv na izbiro poklicne organizacije izbralo največ anketirancev s sidrom izziva - več kot polovica oziroma 53,3 odstotka. Prav tako je možnost izobraževanja precej vplivala tudi na izbiro organizacije pri anketirancih $\mathrm{s}$ sidrom podjetniške ustvarjalnosti (50 odstotkov) in s tehnično-funkcionalnim sidrom $(40,4$ odstotka). Pri menedžerskem sidru je prevladoval 
Tabela 14: Glavni motiv za funkcionalno izobraževanje in usposabljanje glede na prevladujoče karierno sidro

\begin{tabular}{|c|c|c|c|c|c|c|c|c|c|c|c|}
\hline & \multicolumn{8}{|c|}{ Glavni motiv za funkcionalno usposabljanje } & \multirow[b]{2}{*}{ Skupaj } \\
\hline & & & $\begin{array}{l}\text { vedeti } \\
\text { več }\end{array}$ & $\begin{array}{c}\text { uspeh } \\
\text { pri } \\
\text { delu }\end{array}$ & $\begin{array}{l}\text { napre- } \\
\text { dovanje }\end{array}$ & $\begin{array}{c}\text { zaslu- } \\
\text { žiti } \\
\text { več }\end{array}$ & $\begin{array}{c}\text { reší- } \\
\text { tev } \\
\text { težav }\end{array}$ & $\begin{array}{l}\text { prido- } \\
\text { bitev } \\
\text { potrdila }\end{array}$ & $\begin{array}{c}\text { srečanje } \\
\text { s kolegi }\end{array}$ & $\begin{array}{c}\text { želja po } \\
\text { zamenjavi } \\
\text { službe }\end{array}$ & \\
\hline \multirow{16}{*}{$\begin{array}{l}\text { Karierno } \\
\text { sidro } \\
2004\end{array}$} & \multirow{2}{*}{ TFS } & število & 28 & 5 & 2 & 2 & 8 & 1 & 1 & & 47 \\
\hline & & v odstotkih & 59,6 & 10,6 & 4,3 & 4,3 & 17,0 & 2,1 & 2,1 & & 100,0 \\
\hline & \multirow{2}{*}{ MS } & Število & 4 & 6 & 15 & 7 & 1 & & 1 & & 34 \\
\hline & & v odstotkih & 11,8 & 17,6 & 44,1 & 20,6 & 2,9 & & 2,9 & & 100,0 \\
\hline & \multirow{2}{*}{ SSN } & število & 3 & 5 & 3 & 3 & & 2 & & 3 & 19 \\
\hline & & v odstotkih & 15,8 & 26,3 & 15,8 & 15,8 & & 10,5 & & 15,8 & 100,0 \\
\hline & \multirow{2}{*}{ SVS } & število & 5 & 2 & 2 & 2 & 4 & 7 & & & 22 \\
\hline & & $\mathrm{v}$ odstotkih & 22,7 & 9,1 & 9,1 & 9,1 & 18,2 & 31,8 & & & 100,0 \\
\hline & \multirow{2}{*}{ SPU } & število & 5 & 5 & & & & & & & 10 \\
\hline & & v odstotkih & 50,0 & 50,0 & & & & & & & 100,0 \\
\hline & \multirow{2}{*}{ SP } & število & 17 & 13 & 2 & 2 & & & & & 34 \\
\hline & & v odstotkih & 50,0 & 38,2 & 5,9 & 5,9 & & & & & 100,0 \\
\hline & \multirow{2}{*}{ SI } & število & 9 & 2 & 2 & 2 & & & & & 15 \\
\hline & & v odstotkih & 60,0 & 13,3 & 13,3 & 13,3 & & & & & 100,0 \\
\hline & \multirow{2}{*}{ SŽS } & število & 7 & 3 & 1 & 1 & 1 & 1 & & 1 & 15 \\
\hline & & $\mathrm{v}$ odstotkih & 46,7 & 20,0 & 6,7 & 6,7 & 6,7 & 6,7 & & 6,7 & 100,0 \\
\hline \multirow{2}{*}{\multicolumn{2}{|c|}{ Skupaj }} & število & 78 & 41 & 27 & 19 & 14 & 11 & 2 & 4 & 196 \\
\hline & & v odstotkih & 39,8 & 20,9 & 13,8 & 9,7 & 7,1 & 5,6 & 1,0 & 2,0 & 100,0 \\
\hline
\end{tabular}

motiv višine plače, pri sidru varnosti in stabilnosti ugled podjetja, pri sidru življenjskega stila, samostojnosti in neodvisnosti ter sidru predanosti pa medosebni odnosi.

Vrednost hi-kvadrata oziroma Kulbackovega 21. preizkusa ( $\left.k^{2}=73,498, g=28, \dot{a}=0,000\right)$ pokaže, da je vrednost statistično pomembna, in s tveganjem, manjšim od 0,1 odstotka, lahko trdimo, da je prevladujoče karierno sidro posameznika povezano tudi s tem, kakšen pomen daje možnosti za izobraževanje oziroma kakšen vpliv ima ta možnost na izbiro organizacije. Ugotavljanje stopnje povezanosti med spremenljivkama na podlagi kontingenčnega koeficienta $(\mathrm{C}=0,505)$ pokaže, da je poveza- nost med spremenljivkami $v$ vzorcu precejšnja in statistično pomembna ( $\dot{\alpha}=0,000)$. Več kot očitno je, da pri posameznikih s sidrom izziva, sidrom podjetniške ustvarjalnosti in tehnično-funkcionalnim sidrom prevladuje motiv izobraževanje, pri sidru žjvljenjskega stila, samostojnosti in neodvisnosti ter sidru predanosti pa so glavni motiv za to, da organizaciji uspe privabiti kadre, očitno predvsem dobri medosebni odnosi. Glavno sredstvo za pridobitev posameznikov z menedžerskim sidrom pa so očitno materialne nagrade. Pri tem je vsekakor dobrodošlo, da se možnost izobraževanja kot motiv za izbiro organizacije pri vseh kariernih sidrih precej visoko uvršča. 


\section{KARIERNA SIDRA IN \\ MOTIVI ZA FUNKCIONALNO \\ USPOSABLJANJE IN IZOBRAŽEVAN]E PRI DELU}

Iz predstavljenih podatkov je razvidno, da je izobraževanje ne le nujen dejavnik razvoja

Karierna sidra vplivajo tudi na prevladujoč motiv za izobraževanja. posameznika in organizacije, temveč tudi močan motivacijski mehanizem, s katerim lahko organizacija uravnava pozitivno organizacijsko kulturo in zagotavlja visoko raven delovne izvedbe. Izobraževalno pot oziroma posebnosti, podobnosti in razlike pri načrtovanju izobraževalne poti posameznikov $z$ različnimi kariernimi sidri smo v na- daljevanju želeli spremljati pri anketirancih tudi potem, ko so se že zaposlili. S tem namenom smo jih vprašali tudi, kaj je glavni motiv pri funkcionalnem oziroma vseživljenjskem izobraževanju posameznikov potem, ko so se redno zaposlili. Rezultate smo primerjali v prerezu prevladujočih kariernih sider. Podrobnejši rezultati so prikazani v tabeli 14 .

Iz predstavljenih rezultatov lahko sklenemo, da pri menedžerskem sidru prevladuje motiv napredovanja, pri tehnično-funkcionalnem sidru, sidru izziva, sidru življenjskega stila in sidru predanosti pa motiv vedeti več. Pri sidru podjetniške ustvarjalnosti je enakovredno na lestvici motivov za funkcionalno izobraževanje motiv vedeti več skupaj z motivom uspeh

Tabela 15: Način načrtovanja funkcionalnega ixobraževanja in usposabljanja glede na prevladujoče karierno sidro

\begin{tabular}{|c|c|c|c|c|c|c|c|}
\hline & \multicolumn{4}{|c|}{ Svoje izobraževanje načrtujem } & \multirow[b]{2}{*}{ Skupaj } \\
\hline & & & sam & $\begin{array}{l}\text { s kadrovskimi } \\
\text { strokovnjaki }\end{array}$ & $\begin{array}{l}\text { skupaj in } v \\
\text { razgovoru } \\
\mathrm{z} \text { druz̆ino }\end{array}$ & \begin{tabular}{|c|}
$\begin{array}{c}\text { v izobraževanje } \\
\text { me sili } \\
\text { delodajalec }\end{array}$ \\
\end{tabular} & \\
\hline \multirow{16}{*}{$\begin{array}{l}\text { Karierno } \\
\text { sidro } \\
2004\end{array}$} & \multirow{2}{*}{ TFS } & število & 28 & 18 & 1 & & 47 \\
\hline & & $v$ odstotkih & 59,6 & 38,3 & 2,1 & & 100,0 \\
\hline & \multirow{2}{*}{ MS } & Število & 27 & 6 & 1 & & 34 \\
\hline & & v odstotkih & 79,4 & 17,6 & 2,9 & & 100,0 \\
\hline & \multirow{2}{*}{ SSN } & število & 14 & 4 & 1 & & 19 \\
\hline & & $\mathrm{v}$ odstotkih & 73,7 & 21,1 & 5,3 & & 100,0 \\
\hline & \multirow{2}{*}{ SVS } & Število & 7 & 11 & 2 & 2 & 22 \\
\hline & & v odstotkih & 31,8 & 50,0 & 9,1 & 9,1 & 100,0 \\
\hline & \multirow{2}{*}{ SPU } & število & 8 & 2 & & & 10 \\
\hline & & v odstotkih & 80,0 & 20,0 & & & 100,0 \\
\hline & \multirow{2}{*}{ SP } & število & 12 & 16 & 3 & 3 & 34 \\
\hline & & v odstotkih & 35,3 & 47,1 & 8,8 & 8,8 & 100,0 \\
\hline & \multirow{2}{*}{ SI } & število & 11 & 4 & & & 15 \\
\hline & & $\mathrm{v}$ odstotkih & 73,3 & 26.7 & & & 100,0 \\
\hline & \multirow{2}{*}{ SŽS } & število & 2 & 5 & 9 & & 16 \\
\hline & & v odstotkih & 12,5 & 31,5 & 56,3 & & 100,0 \\
\hline \multirow{2}{*}{\multicolumn{2}{|c|}{ Skupaj }} & število & 109 & 66 & 17 & 5 & 197 \\
\hline & & v odstotkih & 55,3 & 33,5 & 8,6 & 2,5 & 100,0 \\
\hline
\end{tabular}


pri delu. Za posameznike s sidrom samostojnosti in neodvisnosti je glavni motiv za funkcionalno izobraževanje in usposabljanje prav tako uspeh pri delu. Pri sidru varnosti in stabilnosti pa prevladuje motiv pridobitev potrdila. Vrednost hi-kvadrata oziroma Kulbackovega 21. preizkusa $\left(\kappa^{2}=129,582, g=49, \dot{\alpha}=0,000\right)$ pokaže, da je vrednost statistično pomembna in lahko s tveganjem, manjšim od 0,1 , trdimo, da so motivi za funkcionalno izobraževanje in usposabljanje $v$ aktivnem zaposlitvenem obdobju odvisni od prevladujočega kariernega sidra posameznika. Ugotavljanje stopnje povezanosti med spremenljivkama na podlagi kontingenčnega koeficienta $(C=0,653)$ pokaže, da je povezanost med spremenljivkami $v$ vzorcu precejšnja in statistično pomembna $(\dot{a}=0,000)$. Na tem mestu smo potrdili hipotezo oz. trditev, da lahko med posamezniki z enakimi kariernimi sidri najdemo podobnosti pri motivih za izobraževanje in hkrati razlike med posameznimi kariernimi sidri.

Prav tako nas je zanimalo, kako posamezniki $\mathrm{z}$ različnimi kariernimi sidri načrtujejo izobraževanje. $S$ tem namenom smo jih povprašali, ali ga načrtujejo sami ali v sodelovanju še s kom (gl. tabelo 15). Prav tako nas je zanimalo, v kakšnem časovnem horizontu posamezniki z različnimi kariernimi sidri načrtujejo izobraževanje, s čimer smo želeli pridobiti podatke, kako razmišljajo o prihodnosti delovne kariere oziroma koliko vnaprej načrtujejo svojo izobraževalno pot (gl. tabelo 16).

Iz pridobljenih podatkov smo ugotovili, da

Tabela 16: Časovno načrtovanje funkcionalnega izobraževanja glede na prevladujoče karierno sidro

\begin{tabular}{|c|c|c|c|c|c|c|c|c|}
\hline & \multicolumn{5}{|c|}{ Časovno načrtovanje izobraževanja } & \multirow[b]{2}{*}{ Skupaj } \\
\hline & & & $\begin{array}{c}\text { ga ne } \\
\text { načrtujem }\end{array}$ & $\begin{array}{l}3 \text { mesece } \\
\text { vnaprej }\end{array}$ & $\begin{array}{c}6 \text { mesecev } \\
\text { vnaprej }\end{array}$ & $\begin{array}{c}1 \text { leto } \\
\text { vnaprej }\end{array}$ & $\begin{array}{c}2 \text { leti } \\
\text { vnaprej }\end{array}$ & \\
\hline \multirow{16}{*}{$\begin{array}{l}\text { Karierno } \\
\text { sidro } \\
2004\end{array}$} & \multirow{2}{*}{ TFS } & število & 5 & 16 & 21 & 2 & 3 & 47 \\
\hline & & v odstotkih & 10,6 & 34,0 & 44,7 & 4,3 & 6,4 & 100,0 \\
\hline & \multirow{2}{*}{ MS } & število & 11 & 7 & 4 & 11 & 1 & 34 \\
\hline & & v odstockih & 32,4 & 20,6 & 11,8 & 32,4 & 2,9 & 100,0 \\
\hline & \multirow{2}{*}{ SSN } & število & 6 & 8 & 5 & & & 19 \\
\hline & & $\mathrm{v}$ odstotkih & 31,6 & 42,1 & 26,3 & & & 100,0 \\
\hline & \multirow{2}{*}{ SVS } & Število & 8 & 10 & 3 & 1 & & 22 \\
\hline & & v odstotkih & 36,4 & 45,5 & 13,6 & 4,5 & & 100,0 \\
\hline & \multirow{2}{*}{ SPU } & število & 5 & 2 & 3 & & & 10 \\
\hline & & v odstotkih & 50,0 & 20,0 & 30,0 & & & 100,0 \\
\hline & \multirow{2}{*}{ SP } & število & 17 & 13 & 2 & 2 & & 34 \\
\hline & & $\mathrm{v}$ odstotkih & 50,0 & 38,2 & 5,9 & 5,9 & & 100,0 \\
\hline & \multirow{2}{*}{ SI } & število & 10 & 1 & 2 & 2 & & 15 \\
\hline & & v odstotkih & 66,7 & 6,7 & 13,3 & 13,3 & & 100,0 \\
\hline & \multirow{2}{*}{ SŽS } & število & 2 & 6 & 7 & 1 & & 16 \\
\hline & & v odstotkih & 12,5 & 37,5 & 43,8 & 6,3 & & 100,0 \\
\hline \multirow{2}{*}{ Skupaj } & & Število & 64 & 63 & 47 & 19 & 4 & 197 \\
\hline & & v odstotkih & 32,5 & 32,0 & 23,9 & 9,6 & 2,0 & 100,0 \\
\hline
\end{tabular}


posamezniki z menedžerskim sidrom, tehnično-funkcionalnem sidrom, sidrom izziva, sidrom podjetniške ustvarjalnosti in sidrom samostojnosti ter neodvisnosti večinoma sami načrtujejo izobraževanje. Skupaj s kadrovskimi strokovnjaki večinoma načrtujejo izobraževanje posamezniki s sidrom varnosti in stabilnosti ter sidrom predanosti, skupaj $\mathrm{z}$ družino oziroma $\mathrm{v}$ razgovoru $\mathrm{z}$ družino pa izobraževanje večinoma načrtujejo posamezniki, pri katerih smo ugotovili prevladujoče sidro življenjskega stila. Zanimivo je tudi, da prav nihče od posameznikov s sidrom izziva in sidrom podjetniške ustvarjalnosti ni navedel, da bi načrtoval izobraževanje na podlagi razgovora z družino. Vrednost hi-kvadrata oziroma Kulbackovega 21. preizkusa $\left(k^{2}=68,508\right.$, $\mathrm{g}=2 \mathrm{l}, \dot{\mathrm{a}}=0,000$ ) pokaže, da je vrednost statistično pomembna, in lahko s tveganjem, manjšim od 0,1 , trdimo, da je tudi način načrtovanja izobraževanja povezan s kariernim sidrom posameznika oziroma da karierno sidro vpliva na njegovo načrtovanje izobraževanja. Ugotavljanje stopnje povezanosti med spremenljivkama na podlagi kontingenčnega koeficienta ( $C=0,550$ ) pokaže, da je povezanost med spremenljivkami $\mathrm{v}$ vzorcu precejšnja in statistično pomembna ( $\alpha=0,000$ ).

Časovna dimenzija načrtovanja izobraževanja nam lahko pove nekaj več o tem, kako posamezniki načrtujejo svojo kariero. Nekateri svoje izobraževanje načrtujejo več let vnaprej, drugi pa so osebe nenadnih odločitev in se za izobraževanje odločijo tik pred zdajci. To vprašanje vsekakor zanima vse izobraževalne institucije, ki pripravljajo programe izobraževanja, prav tako pa tudi izobraževalne centre v organizacijah, ki načrtujej̧o izobraževalne vsebine. Navsezadnje z vpogledom v časovno načrtovanje izobraževanja lahko dobimo tudi odgovor na to, kako si posamezniki načrtujejo kariero, kakšne cilje si postavijo in ali so ti cilji kratkoročne ali dolgoročne narave. Anketirance smo torej povprašali tudi po tem, kako daleč vnaprej načrtujejo izobraževanje (gl. tabelo 16). Pri posameznikih z menedžerskim sidrom smo dvakrat dobili največ odgovorov, 32,4 odstotka, in sicer menedžerji v enakem odstotku načrtujejo izobraževanje leto dni vnaprej oziroma ga sploh ne načrtujejo. $V$ zvezi s tehnično-funkcionalnim sidrom in sidrom življenjskega stila smo ugotovili, da jih največ načrtuje izobraževanje pol leta vnaprej. Večina posameznikov s sidrom varnosti in stabilnosti ter sidrom samostojnosti in predanosti načrtuje izobraževanje tri mesece vnaprej. Največje število posameznikov s prevladujočim sidrom izziva ter sidrom predanosti pa izobraževanja sploh ne načrtuje vnaprej in je zanje očitno funkcionalno izobraževanje in usposabljanje $v$ zvezi $z$ delom večinoma trenutna odločitev ali trenutna potreba. Vrednost hi-kvadrata oziroma Kulbackovega 21. preizkusa $\left(k^{2}=76,716, g=28, \dot{a}=0,000\right)$ pokaže, da je vrednost statistično pomemb$n a$, in lahko s tveganjem, manjšim od 0,1 odstotka, trdimo, da je časovno načrtovanje izobraževanja povezano s kariernim sidrom posameznika oziroma karierno sidro vpliva na časovno dimenzijo načrtovanja posameznikovega izobraževanja. Ugotavljanje stopnje povezanosti med spremenljivkama na podlagi kontingenčnega koeficienta $(C=0,529)$ pokaže, da je povezanost med spremenljivkami $v$ vzorcu precejšnja in statistično pomembna $(\dot{\alpha}=0,000)$.

\section{KARIERNA SIDRA TER RAZPRŠENOST IZOBRAŽEVANJA}

Tudi raznolikost izobraževalnih področij je lahko pomemben kazalec načrtovanja kariere. Pri nekaterih ljudeh opažamo, da je njihovo izobraževanje izjemno razpršeno, zanima jih vrsta različnih področij in želijo biti čimbolj podučeni, zato se odločajo za raznolike in pestre izobraževalne vsebine. Pri drugih pa ugo- 
Tabela 17: Raznolikost in raxpršenost ixobraževanja glede na prevladujoče karierno sidro

\begin{tabular}{|c|c|c|c|c|c|c|c|c|}
\hline & \multicolumn{5}{|c|}{ Razpršenost izobraževalnih vsebin } & \multirow[b]{2}{*}{ Skupaj } \\
\hline & & & $\begin{array}{c}\text { eno } \\
\text { področje }\end{array}$ & $\begin{array}{c}\text { dve } \\
\text { področji }\end{array}$ & $\begin{array}{c}\text { tri } \\
\text { področja }\end{array}$ & $\begin{array}{c}\begin{array}{c}\text { štiri } \\
\text { področja }\end{array} \\
\end{array}$ & $\begin{array}{c}\text { pet področij } \\
\text { ali več }\end{array}$ & \\
\hline \multirow{16}{*}{$\begin{array}{l}\text { Karierno } \\
\text { sidro } \\
2004\end{array}$} & \multirow{2}{*}{ TFS } & število & 28 & 15 & 4 & & & 47 \\
\hline & & v odstotkih & 59,6 & 31,9 & 8,5 & & & 100,0 \\
\hline & \multirow{2}{*}{ MS } & število & & 5 & 23 & 3 & 3 & 34 \\
\hline & & v odstotkih & & 14,7 & 67,6 & 8,8 & 8,8 & 100,0 \\
\hline & \multirow{2}{*}{ SSN } & število & 6 & 4 & 7 & 1 & & 18 \\
\hline & & v odstotkih & 33,3 & 22,2 & 38,9 & 5,6 & & 100,0 \\
\hline & \multirow{2}{*}{ SVS } & število & 12 & 8 & 2 & & & 22 \\
\hline & & v odstotkih & 54,5 & 36,4 & 9,1 & & & 100,0 \\
\hline & \multirow{2}{*}{ SPU } & število & 1 & 1 & 5 & 3 & & 10 \\
\hline & & v odstotkih & 10,0 & 10,0 & 50,0 & 30,0 & & 100,0 \\
\hline & \multirow{2}{*}{$\mathrm{SP}$} & število & 15 & 17 & 2 & & & 34 \\
\hline & & v odstotkih & 44,1 & 50,0 & 5,9 & & & 100,0 \\
\hline & \multirow{2}{*}{ SI } & število & 2 & 3 & 3 & 4 & 3 & 15 \\
\hline & & v odstotkih & 13,3 & 20,0 & 20,0 & 26,7 & 20,0 & 100,0 \\
\hline & \multirow{2}{*}{ sŽS } & število & 2 & 10 & 4 & & & 16 \\
\hline & & v odstotkih & 12,5 & 62,5 & 25,0 & & & 100,0 \\
\hline \multirow{2}{*}{\multicolumn{2}{|c|}{ Skupaj }} & število & 66 & 63 & 50 & 11 & 6 & 196 \\
\hline & & v odstotkih & 33,7 & 32,1 & 25,5 & 5,6 & 3,1 & 100,0 \\
\hline
\end{tabular}

tavljamo, da se želijo izmojstriti le na enem področju in jih druga področja ne pritegnejo. Pri iskanju podobnosti oziroma razlik pri načrtovanju izobraževanja med posamezniki $\mathrm{z}$ različnimi kariernimi sidri nas je torej tudi zanimalo, kako raznovrstno je njihovo izobraževanje. Povprašali smo jih, na koliko (popolnoma) različnih področjih so se (neformalno) izobraževali v preteklem letu. Različno področje je na primer pomenilo: a) področje financ, b) področje strateškega menedžmenta, c) področje prava, d) področje medosebnega komuniciranja ..., in ne različne vrste izobraževanja v okviru enakega strokovnega ali poslovnega področja. Rezultati, podrobno predstavljeni v tabeli 17 , so izjemno zanimivi, saj nakazujejo na večje razlike med kariernimi sidri.

Iz tabele je razvidno, da si najbolj raznoliko izobraževanje "privoščijo " posamezniki s sidrom izziva, 20 odstotkov izmed njih se jih je izobraževalo na petih ali več področjih letno, 26,7 odstotka pa na štirih različnih področjih. Sledijo jim posamezniki s prevladujočim menedžerskim sidrom, ki so se največkrat izobraževali na treh različnih področjih na leto $(67,6$ odstotka), na štirih oziroma petih in več pa 8,8 odstotka. Najpogosteje so se le na enem področju izobraževali posamezniki s tehnično-funkcionalnim sidrom, 59,6 odstotka, in posamezniki s sidrom varnosti in stabilnosti. Na dveh področjih na leto pa se 
v največjem številu izobražujejo posamezniki s sidrom življenjskega stila, sidrom samostojnosti in neodvisnosti ter sidrom predanosti.

\section{Razpršenost izob- raževanja lahko povežemo s karier- nim sidrom.}

Sicer pa se jih največ še vedno izobražuje večinoma le na enem oziroma dveh področjih na leto. Vrednost hi-kvadrata oziroma Kulbackovega 21. preizkusa $\left(\kappa^{2}=135,464, g=\right.$ $28, \dot{a}=0,000$ ) pokaže, da je vrednost statistično pomembna in da lahko $\mathrm{s}$ tveganjem, manjšim od 0,1 odstotka, trdimo, da je vsebinska razpršenost izobraževanja povezana $s$ kariernim sidrom posameznika. Ugotavljanje stopnje povezanosti med spremenljivkama na podlagi kontingenčnega koeficienta ( $C=0,641)$ pokažc, da je povezanost med spremenljivkami $v$ vzorcu precejšnja in statistično pomembna $(\dot{\alpha}=0,000)$.

$S$ preizkušanjem statističnih vrednosti spremenljivk ter povezanosti med njimi smo potrdili hipotezo, da je izobraževanje sestavni del razvoja kariere in lahko razvoj kariere nadomestimo $s$ pojmom izobraževalna pot, saj smo ugotovili pomembne razlike pri načrtovanju izobraževanja vzdolž posameznih kariernih sider.

\section{ZAKLJUČEK}

$\mathrm{V}$ raziskavi smo najprej s posebnim vprašalnikorn na priložnostnem vzorcu identificirali prevladujoča karierna sidra $v$ zvezi z 12 poklici. Šlo je za vzorec, ki ga lahko glede izobrazbene strukture označimo kot nadpovprečen. $\mathrm{Na}$ enakem vzorcu smo čez štiri leta ponovno preverili prevladujoča karierna sidra $\mathrm{z}$ enakim vprašalnikom $\mathrm{z}$ namenom, da bi ugotovili, ali se karierna sidra spreminjajo. Izkazalo se je, da se večinoma niso spremenila, oziroma se niso več spreminjala pri tistih posameznikih, ki so imeli več kot 10 let delovnih izkušenj. Motiv za izbrano karierno pot se torej izostri v prvih letih delovnih izkušenj na podlagi povratnih informacij, ki jih posameznik pridobiva o svojem delu, uspešnosti pri delu in zadovoljstvu $\vee$ zvezi $z$ delom. Na podlagi identifikacije kariernih sider smo nato s posebnim vprašalnikom skušali najti podobnosti in razlike tudi pri načrtovanju izobraževanja. Razlike in podobnosti pri načrtovanju izobraževanja, ki smo jih ugotavljali v raziskavi na podlagi iskanja vrednosti hi-kvadrata oziroma Kulbackovega 21. preizkusa, so pokazale, da lahko tudi načrtovanje kariere povežemo s prevladujočimi kariernimi sidri. Hkrati pa se je $v$ raziskavi izkristaliziral pomen izobraževanja glede obsega in razpršenosti za načrtovanje kariere.

$\mathrm{V}$ zadnjem, tretjem delu bomo skozi rezultate raziskave osvetlili še povezanost kariernih sider $z$ uresničevanjem kariernih ambicij.

\section{LITERATURA}

Bischoff, L. L. (1969). Adult Psihology. New York: Harper and Row.

Brečko, D. (1997). Prihodnost ustvarjamo ljudje. Andragoška spoznanja, 3, str. I.

Brečko, D. (1998). Kako se odrasli spreminjamo. Radovljica: Didakta.

Brečko, D. (2000). Karierna sidra v Sloveniji. Raziskava. Ljubljana: GV Izobraževanje.

Brečko, D. (2001). Ali načrtujete svojo kariero? 4. HRM konferenca, Catež.

Brecko, D. (2002). Zapisi pogovorov o načrtovanju ka riere. Ljubljana.

Brě̌ko, D. (2002a). Načrtovanje in razvoj nasledstev v zavarovalnici Triglav, OE Murska Sobota. Projektna naloga. Ljubljana.

Btě̌ko, D. (2004). Karierna sidra in načrtovanje izobraževanja. Raziskava, GV Izobraževanje.

Erikson, E. H. (1959). Identity and the life cycle. Psychological issues, I, str. 1-171.

Erikson, E. H. (1980). Identity and the life cycle. New York: Systems.

Ginzberg, E., Ginsburg, S. W., Axelrad, S., Herma, J. L. (1951). Occupational Choice: An approach to general theory. New York: Columbia University Press.

Kožuh, B. (2003). Statistične metode v pedagoškem raziskovanju. Ljubljana: Filozofska fakulteta.

Krajnc, A. (1985). Oseben pristop v samostojnem učenju. Ljubljana: Filozofska fakulteta.

Krajnc, A. (1995). Kdo naj odloča o tem, česa naj se ljudje uð̌jjo? Andragoška spoznanja, 1, str. 17-21. 
Krajnc, A. (1996). Kakšno znanje potrebuje sodobni človek. Andragoška spoznanja, 3, str. 5-10.

Krajnc, A. (1997). Kako živimo zadnjih trideset let življenja. Rast, 1-2, str. 47-48, Andragoška spoznanja 1995, st. I, str. 17-21.

Leibowitz, Z., Schlossberg, N. (1982). Critical Career Transitions: A Model for Designing Career Services. Training and Development Journal, februar, str. 13-19. Leibowitz, Z., Farren, C., Kaye, B. (1983). Will Your Organization Be Doing Career Development in the Year 2000? Training and Development Joutnal, str. 14-20.

Leibowitz, Z., Farsen, C., Kaye, B. (1990). Designing Career Development System. San Francisco: JosseyBass Publishers.

Leibowitz, Z., Hirsh, S. (ur.) (1984). Career Development: Current Perspectives. Washington, D. C.: ASTD Press.

Leibowitz, Z., Schlossberg, N. K., Shore, J. E. (1991). Stopping the Revolving Door. Training and Development Journal, februar, str. 43-50.

Lipičnik, B. (1998). Ravnanje z ljudmi pri delu. Ljubljana: Gospodarski vestnik.

Mayer J. (199]). Kako iz krize dela do zaposlitve. VI. Studijski dnevi kadrovskih delavcev Slovenije, Portorož. McGarrell, E. J. (1983). An Orientation System that Builds Productivity. Personnel, 60, let. 6, str. 32-41.

McLagan, P. A. (1989). Models for HRD Practice. Training and Development, 43 (9), str. 49-59.

Muršak, J. (2002). Poklicna socializacija, pojem in temeljne značilnosti. V Medveš, Z., Muršak, J., Pojmovni slovar za področje poklicnega in strokovnega izobraževanja. Ljubljana: Ministrstvo za Solstvo in Šport - Urad RS za solstvo.

Schein, E. H. (1971). The Individual, the Organization, and the Career: A Conceptual Scheme. Journal of Applied Behavioral Science. 7, str. 401-426.

Schein, E. H. (1978). Career Dynamics: Matching Indiyidual and Organizational Needs, Reading, Mass.: Addison-Wesley.

Swanson, R. A., Holton E. F. (1997). Human Resource Development Handbook: Linking Research and Practice. San Francisco: Berrett-Koehler.

Toffler, A. (1975), Šok budučnosti. Rijeka: Otokar Kerševani.

Troll, L. E. (1975). Early and Middle Adulthood. Monterey, California: Brooks/Cole.

Van Maanen, J. (1973). Observation of the making of Policemen, Human Organization, 4, str. 407-418.

Wachter, M. (2000). Druga kariera. Dnevi strokovnega izpopolnjevanja tajnic, Portorož 2000. Seminarsko gradivo. Ljubljana: GV Izobraževanje.

Walker, J. W. (1973). Individual Carcer Planning. Business Horizons, februar, str. 69.

Zunker, V. G. (1998). Career Couseling, Applied Concepts of life planning. Grove, CA: Brooks/Cole Publishing Company.
' Pri rem je rreba znova poudariti opredelitev samega poklica, kakor jo navaja tudi Standardna klasifikacija poklicev ( $S K P$, Urad za statistiko RS). Poklic je dejav. nost, ki jo posameznik trenutno opravlja in se torej po Standardni klasifikacïi poklicev ne enači s pridobljeno stopnjo formaine izobrazbe, temveč z delom. Tako je na primer nekdo lahko po izobrazbi univerzitetni diplomirani novinar, trenutno pa opravlja delo urednika knjižne zbirke za miadino, torej je po poklicu urednik in ne novinar. Č je nekdo izučen kovinostrugar, vendar opravija dela čvljarja, je po poklicu čevljar. Č zamenja službo in začne opravljati delo recimo avtomehanika, postane po poklicu avtomehanik. 